\title{
Effects of Chronic Social Defeat Stress on Sleep and Circadian Rhythms Are Mitigated by Kappa-Opioid Receptor Antagonism
}

\author{
Audrey M. Wells, ${ }^{1}$ Elysia Ridener, ${ }^{1}{ }^{\mathbb{C} C l i n t o n}$ A. Bourbonais, ${ }^{2}$ Woori Kim, ${ }^{1}{ }^{\circ}$ Harry Pantazopoulos, ${ }^{1}$ F. Ivy Carroll, ${ }^{3}$ \\ 'OKwang-Soo Kim, ${ }^{1}$ Bruce M. Cohen, ${ }^{1}$ and William A. Carlezon, Jr. ${ }^{1}$ \\ ${ }^{1}$ Basic Neuroscience Division, Department of Psychiatry, Harvard Medical School, McLean Hospital, Belmont, Massachusetts 02478, ${ }^{2}$ Pfizer, Cambridge, \\ Massachusetts 02139, and ${ }^{3}$ Research Triangle Institute, Durham, North Carolina 27709
}

Stress plays a critical role in the neurobiology of mood and anxiety disorders. Sleep and circadian rhythms are affected in many of these conditions. Here we examined the effects of chronic social defeat stress (CSDS), an ethological form of stress, on sleep and circadian rhythms. We exposed male mice implanted with wireless telemetry transmitters to a 10 day CSDS regimen known to produce anhedonia (a depressive-like effect) and social avoidance (an anxiety-like effect). EEG, EMG, body temperature, and locomotor activity data were collected continuously during the CSDS regimen and a 5 day recovery period. CSDS affected numerous endpoints, including paradoxical sleep (PS) and slow-wave sleep (SWS), as well as the circadian rhythmicity of body temperature and locomotor activity. The magnitude of the effects increased with repeated stress, and some changes (PS bouts, SWS time, body temperature, locomotor activity) persisted after the CSDS regimen had ended. CSDS also altered mRNA levels of the circadian rhythm-related gene $m P e r 2$ within brain areas that regulate motivation and emotion. Administration of the $\kappa$-opioid receptor (KOR) antagonist JDTic ( $30 \mathrm{mg} / \mathrm{kg}$, i.p.) before CSDS reduced stress effects on both sleep and circadian rhythms, or hastened their recovery, and attenuated changes in $m$ Per2. Our findings show that CSDS produces persistent disruptions in sleep and circadian rhythmicity, mimicking attributes of stress-related conditions as they appear in humans. The ability of KOR antagonists to mitigate these disruptions is consistent with previously reported antistress effects. Studying homologous endpoints across species may facilitate the development of improved treatments for psychiatric illness.

Key words: EEG; gene expression; kappa-opioid receptor; mice; sleep; stress

\section{Significance Statement}

Stress plays a critical role in the neurobiology of mood and anxiety disorders. We show that chronic social defeat stress in mice produces progressive alterations in sleep and circadian rhythms that resemble features of depression as it appears in humans. Whereas some of these alterations recover quickly upon cessation of stress, others persist. Administration of a kappa-opioid receptor (KOR) antagonist reduced stress effects or hastened recovery, consistent with the previously reported antistress effects of this class of agents. Use of endpoints, such as sleep and circadian rhythm, that are homologous across species will facilitate the implementation of translational studies that better predict clinical outcomes in humans, improve the success of clinical trials, and facilitate the development of more effective therapeutics.

\section{Introduction}

Stress plays a prominent role in the etiology and pathophysiology of psychiatric illness. One domain that is consistently dysregulated in many of these illnesses is circadian function, including regulation of sleep (American Psychiatric Association, 2013). In

Received April 1, 2017; revised June 22, 2017; accepted June 28, 2017.

Author contributions: A.M.W., H.P., B.M.C., K.-S.K., and W.A.C. designed research; A.M.W., E.R., and W.K. performed research; F.I.C. contributed unpublished reagents/analytic tools; A.M.W., E.R., C.A.B., and W.K. analyzed data; A.M.W. and W.A.C. wrote the paper.

This work was supported by National Institutes of Health Grant MH063266 to W.A.C.

W.A.C. has several patents for the use of kappa ligands to treat psychiatric illness (assignee McLean Hospital) and in the last 3 years has served as a consultant for Cerecor. A.M.W. performed this research as a individuals with mood and anxiety disorders (e.g., major depressive disorder [MDD], generalized anxiety, post-traumatic stress disorder), this can manifest as increased or decreased sleep, fragmented sleep patterns that reflect more frequent bouts of sleep and wakefulness, and/or arrhythmic activity or physiology. There is considerable evidence in the literature that stress disrupts sleep

postdoctoral fellow at McLean Hospital but is presently an employee of Pfizer. The remaining authors declare no competing financial interests.

Correspondence should be addressed to Dr. William A. Carlezon, Jr, Department of Psychiatry, McLean Hospital, 115 Mill Street, Belmont, MA 02478. E-mail: bcarlezon@mclean.harvard.edu.

DOI:10.1523/JNEUROSCI.0885-17.2017

Copyright $\odot 2017$ the authors $\quad 0270-6474 / 17 / 377656-13 \$ 15.00 / 0$ 
in people (Ross et al., 1989) and laboratory animals (Pawlyk et al., 2008), although the neural mechanisms of these effects are not thoroughly understood. A better understanding of these mechanisms may facilitate the development of approaches to treat or prevent the effects of stress on sleep, which patients find particularly debilitating.

One method to study the effects of acute and chronic stress in mice is the chronic social defeat stress (CSDS) paradigm. This technique involves an ethological form of stress related to territorial aggression in mice (Golden et al., 2011) and has numerous advantages for understanding the ways in which behavioral and molecular adaptations develop over time in response to stressful experiences. One advantage is that key behavioral endpoints that are altered by CSDS (e.g., social interaction) are sensitive to chronic but not acute treatment with standard antidepressants (Berton et al., 2006) and acute treatment with ketamine (Donahue et al., 2014), both of which resemble the time courses of therapeutic drug actions in humans (Zarate et al., 2006). In addition, CSDS can reveal separate "susceptible" and "resilient" populations, potentially modeling individual differences in stress susceptibility in humans (Krishnan et al., 2007). Importantly, CSDS effects can endure beyond termination of the stressor (Donahue et al., 2014), making it a particularly appealing method with which to study some of the persistent characteristics of stressrelated psychiatric illnesses as they occur in clinical settings.

Seminal studies of CSDS-induced adaptations have examined endpoints after a CSDS regimen. For example, a 10 day CSDS regimen produces avoidance behaviors in social interaction tests conducted the day after the final defeat session (Berton et al., 2006). We have used the intracranial self-stimulation test to track the development of day-by-day adaptations in behavior over $10 \mathrm{~d}$ of CSDS (Donahue et al., 2014, 2015). These studies demonstrate that CSDS produces gradual, rather than all-or-none, increases in the emergence of anhedonia (reduced sensitivity to reward), a core feature of depressive disorders, and that these effects are persistent (Donahue et al., 2014). The ability to precisely follow the time course over which anhedonia and other signs develop and recover may provide deeper insight into susceptibility and resilience to stress, as well as fundamental relationships between behavioral and molecular adaptations triggered by stress exposure.

The primary purpose of the present work is to develop a detailed understanding of the time course over which CSDS produces alterations in sleep and circadian rhythm, and the persistence of these effects. We used a wireless telemetry system involving an implantable subcutaneous transmitter that enables free, untethered movement in mice and analysis of endpoints, including EEG, EMG, body temperature, and locomotor activity. The transmitters provide continuous telemetry, enabling realtime measurement of sleep and circadian rhythms during baseline, stress exposure, and recovery periods. We also quantified expression of a gene (mPer 2$)$ often used as a readout of circadian rhythmicity (Welsh et al., 2010) and implicated in anxiety (Spencer et al., 2013) to confirm that molecular adaptations occur in parallel to behavioral adaptations. Finally, because there is accumulating evidence from our laboratory and others that $\kappa$-opioid receptor (KOR) antagonists can attenuate and/or prevent the effects of stress (Pliakas et al., 2001; Beardsley et al., 2005; Knoll et al., 2007; Carlezon and Krystal, 2016), we examined in a subset of mice whether pretreatment with a long-lasting KOR antagonist (JDTic) would also mitigate CSDS effects on these endpoints.
Table 1. Vigilance states as defined by Neuroscore

\begin{tabular}{lllll}
\hline Vigilance state & Delta power & Theta power & Muscle tone & Movement \\
\hline Active wake & Low & Low & High & Any \\
Quiet wake & Low-mid & Low-high & Low-mid & NA \\
SWS & Mid-high & Low-mid & Low-mid & NA \\
PS & Low & High & Low & NA \\
\hline
\end{tabular}

\section{Materials and Methods}

Animals. Male C57BL/6J mice (6-8 weeks old; The Jackson Laboratory) were pair-housed upon arrival and then individually housed following surgery $\sim 1$ week later. Mice were maintained in a temperature- and humidity-controlled vivarium under a $12 \mathrm{~h}$ light/dark (9:00 A.M./9:00 P.M.) cycle. CD1 male mice (retired breeders; Charles River Laboratories) served as aggressors during CSDS and were individually housed in the same vivarium for the duration of the experiment. Food and water were available ad libitum. The housing and treatment of experimental animals were approved by the McLean Hospital Institutional Animal Care and Use Committee and followed guidelines set by the National Institutes of Health.

Surgery. The C57BL/6J ("target") mice were anesthetized with intraperitoneal injections of ketamine/xylazine $(80 / 10 \mathrm{mg} / \mathrm{kg})$ and implanted with wireless PhysioTel F20-EET (Data Sciences International) biotelemetry transmitters. Surgical procedures followed specifications provided by the manufacturer. Briefly, mice were placed into a stereotaxic instrument. The transmitter was inserted into a subcutaneous pocket on the back, just lateral to the spine and approximately midway between the neck and hind legs. Next, two surface EEG electrodes (biopotential leads tethered to miniature stainless-steel screws) were implanted over the left frontal lobe (Site 1: anteroposterior $1.0 \mathrm{~mm}$, mediolateral $1.00 \mathrm{~mm}$, relative to bregma) and the contralateral parietal lobe (Site 2: anteroposterior $-3.0 \mathrm{~mm}$, mediolateral $-3.00 \mathrm{~mm}$, relative to bregma) and lowered until they made contact with dura. These coordinates have been shown to permit long-term, stable EEG recordings in mice (Tang and Sanford, 2002). Electrodes were secured in place with dental cement. Then, two biopotential leads (EMG electrodes) were inserted through small incisions made using a $21 \mathrm{G}$ needle in the cervical trapezius muscle and secured with nondissolvable silk sutures. The incision site was closed with silk sutures and treated with a local anesthetic ( $2 \%$ lidocaine) and a topical antibiotic (triple antibiotic ointment). Mice were given $14 \mathrm{~d}$ of postoperative recovery before measurement of baseline physiological metrics began.

Physiological recordings (EEG, EMG, body temperature, motor activity). Target mice were individually housed following surgery in standard Plexiglas home cages placed on RPC-1 PhysioTel receivers (DSI), which detect signals from the transmitters. Receivers are connected to a data exchange matrix (DSI), which relays continuous and simultaneous EEG, EMG, motor activity, and body temperature signals to a computer equipped with Dataquest ART Platinum (DSI). EEG data were analyzed in Neuroscore (DSI). Vigilance states, including active wakefulness (AW), slow-wave sleep (SWS), and paradoxical sleep (PS), were assigned to each $10 \mathrm{~s}$ epoch using an automated scoring algorithm in Neuroscore that uses established relationships between power and activity to classify waveforms into particular vigilance states (Table 1).

Vigilance state durations (time in minutes) and bouts (number of discrete episodes) were calculated for $1 \mathrm{~h}, 1 \mathrm{~d}$, or $10 \mathrm{~d}$ blocks. Additionally, for each vigilance state, spectral power was quantified from the raw EEG signal using a multitaper method. Analysis was run using a custom MATLAB script (Pfizer) using the Chronux toolbox. The frequency bands used were defined as follows: delta $(0.5-4 \mathrm{~Hz})$, theta $(4-12 \mathrm{~Hz})$, low gamma $(30-58 \mathrm{~Hz})$, and high gamma $(62-100 \mathrm{~Hz})$. Power analyses were performed for baseline day 5 (i.e., the day preceding the onset of CSDS), defeat day 1 , and defeat day 10 . The amplitude of body temperature and motor activity rhythms was calculated using CLOCKLAB. All data are expressed as a percentage of baseline.

Drugs. JDTic (Research Triangle Institute) was dissolved in $0.9 \%$ saline for a final concentration of $30 \mathrm{mg} / \mathrm{kg}$. This dose of JDTic has previously been shown to block corticotropin-releasing factor-enhanced 
startle (an anxiogenic-like reflexive behavior) in mice (Van't Veer et al., 2013 b). JDTic or vehicle (0.9\% saline) was administered intraperitoneally on baseline day 4 to accommodate the delayed increase in KOR selectivity following JDTic administration ( $\sim 24 \mathrm{~h}$ post-injection; Carroll et al., 2004).

CSDS. Following postoperative recovery, baseline physiological recordings were obtained for 5 consecutive days. Thereafter, mice were randomly assigned to receive either CSDS or control conditions; in Experiment 2, cohorts of mice received vehicle or JDTic before the stress regimen began. Our CSDS procedure has been described in detail (Golden et al., 2011; Donahue et al., 2014). Briefly, for 10 consecutive days, at zeitgeber time (ZT) 0 (9:00 A.M.), C57BL/6J mice were placed for 10 min into the homecage of novel resident CD1 mice that had been previously screened for aggressive behavior. This reliably elicits high levels of territorial aggression in the CD1 mouse that is directed at the C57BL/6J mouse. Following this physical interaction period, a perforated Plexiglas partition was inserted in the cage to separate the mice while still allowing for continuous, protected sensory exposure. The procedure was repeated for $10 \mathrm{~d}$, using a new $\mathrm{CD} 1$ resident mouse each day to maintain high levels of aggression. Control mice were handled and pair-housed opposite a new conspecific C57BL/6J mouse on each day but in the absence of direct physical interaction.

Social interaction (SI) test and division of mice into susceptible and resilient subpopulations. Social avoidance is a key symptom of depressive disorders, and previous work has shown that CSDS produces this behavior in defeated mice (Golden et al., 2011; Donahue et al., 2014). Importantly, this behavioral endpoint can reveal subgroups of mice that are stress-susceptible or resilient (Berton et al., 2006; Krishnan et al., 2007). We performed an initial set of studies (Experiment 1) to confirm that the transmitters and EEG/EMG assemblies were sufficiently durable to survive the 10 day CSDS procedure, and to determine whether the basic characteristics of social interaction behavior were normal in mice implanted with the subcutaneous transmitters. Mice were habituated to a social interaction arena $(42 \times 42 \times 42 \mathrm{~cm})$ for 20 min immediately after the social defeat session on defeat days 9 and 10; this minor modification of a more widely used procedure (Golden et al., 2011) produces more reliable social avoidance behavior under our testing conditions (Donahue et al., 2014, 2015). SI was assessed on the day following the last CSDS session, as described previously (Donahue et al., 2014). SI scores were calculated as the amount of time spent near a social target compared with time spent near an empty enclosure. In previous studies, an SI score of 1 has been used as an index to quantify stress susceptibility ( $\mathrm{SI}<1$, stresssusceptible; SI $>1$, stress-resilient) after CSDS (Krishnan et al., 2007). These same studies indicated that CSDS reduces the amplitude of circadian rhythm of body temperature in susceptible but not resilient mice, offering a secondary biomarker with which to differentiate these phenotypes. Because we found that SI scores were similar in both groups, raising the possibility that the presence of the subcutaneous transmitter changes the fundamental microstructure of social interaction behavior, we instead focused on temperature amplitude, and performed a median split of the temperature amplitude during CSDS, expressed as a percentage of the baseline value to classify mice as susceptible $(<$ median $)$ or resilient ( $\geq$ median). Data from Experiment 1 confirmed that the existence of two nonoverlapping subpopulations of defeated mice: those with blunted temperature amplitude (susceptible) and those with negligible changes (resilient). As such, we also used this median-split approach to segregate the mice for subsequent studies (Experiment 2), which did not include SI tests.

$q R T-P C R$. To confirm that CSDS causes alterations in cellular pathways known to regulate circadian rhythms, a subset of mice $(N=6$ or 7 per group) were killed on postdefeat day 5 at ZT1 via cervical dislocation, and brains were rapidly removed, flash frozen in ice-cold isopentane, and stored at $-80^{\circ} \mathrm{C}$. Brains were sectioned on a cryostat, and $19 \mathrm{Ga}$ tissue punches were taken from the VTA, amygdala (AMG; basolateral nuclei), NAc (comprising the shell and core subregions), and medial PFC (comprising the prelimbic and infralimbic cortices); $30 \mu \mathrm{m}$ sections from each region were then mounted on slides to document the location and quality of the dissection. RNA was extracted using GeneJET RNA Purification Kit (Thermo Scientific), and quantity and quality were evaluated using a
NanoDrop 2000 Spectrophotometer (Thermo Scientific). cDNA was generated from $100 \mathrm{ng}$ of RNA with the SuperScript III First-Strand Synthesis Kit (Invitrogen). The forward (GAGTGTGTGCAGCGGCTTAG) and reverse (GTAGGGTGTCATGCGGAAGG) primers for mPer2 were chosen based on previous work (Spencer et al., 2013).

In a mixture with $2 \times$ SsoAdvanced Universal SYBR Green Supermix (Bio-Rad), qRT-PCR was run on the CFX Connect Real-Time System (Bio-Rad) in a volume of $20 \mu \mathrm{l}$, with $0.2 \mu \mathrm{l}$ of forward and reverse primers (100 ng/ $\mu \mathrm{l} \mathrm{each)}$ and $1.0 \mu \mathrm{l}$ cDNA sample. PCR cycling conditions were as follows: $95^{\circ} \mathrm{C}$ for $30 \mathrm{~s}, 60$ cycles at $95^{\circ} \mathrm{C}$ for $15 \mathrm{~s}$ each, $55^{\circ} \mathrm{C}$ for $30 \mathrm{~s}$, and $72^{\circ} \mathrm{C}$ for $30 \mathrm{~s}$. Data were collected at a read temperature of $72^{\circ} \mathrm{C}$, based on a melt curve of $65^{\circ}-95^{\circ} \mathrm{C}$, increased in increments of $0.5^{\circ} \mathrm{C}$ for $5 \mathrm{~s}$ each.

Statistical analyses. Analyses were performed using SPSS. SI scores (time near social target/time spent near an empty enclosure) in defeated mice and in controls were directly compared using Student's $t$ tests. Total time in interaction zone, center time, corner time, number of entries into and latency to enter the interaction zone, and distance traveled were analyzed using two-way ANOVAs with repeated measures, where trial (empty enclosure or social target present) was the within-subjects factor and group (Control or Defeat) was the between-subjects factor. Data quantifying sleep, qEEG, and circadian rhythmicity analyzed using twoway ANOVAs with repeated measures where appropriate. Effects on mRNA levels across brain regions were analyzed using a three-way ANOVA with repeated measures. Significant effects were further examined with Bonferroni's post hoc tests. The effects of JDTic on the rate of change in PS bouts during CSDS and recovery were evaluated using separate linear regression analyses for vehicle- and JDTic-treated mice on defeat days $1-5$, defeat days $6-10$, and postdefeat days $1-5$, and the standardized $\beta$-coefficient for the slope of each line was compared with 0 (indicative of no change).

\section{Results}

Feasibility of CSDS in mice with subcutaneous transmitters

In Experiment 1, we assessed the feasibility of conducting CSDS in mice implanted with subcutaneous transmitters using three endpoints: SI, circadian rhythm of body temperature, and motor activity. EEG/EMG signals were not analyzed in detail because the SI procedure (two habituation sessions plus the test) interrupted the light/inactive phase, producing potentially confounding effects. Under our experimental conditions, CSDS did not produce social avoidance in defeated mice. Time spent in the interaction zone in the presence versus absence of a social target depended on a main effect of trial only $\left(F_{(1,13)}=11.87, p=0.004\right)$. Both groups spent more time in the interaction zone when the enclosure contained a social target than when it was empty (Fig. 1A). Both groups also had similar SI scores (Fig. 1C), and the distribution was unimodal rather than bimodal (Krishnan et al., 2007) (Fig. $1 D)$. There were no group differences in distance traveled, corner time, or the number of entries into or latency to enter the interaction zone (data not shown). However, time spent in the center of the interaction arena depended on a trial $\times$ group interaction $\left(F_{(1,13)}=4.81, p=0.047\right)$ (Fig. $\left.1 C\right)$, with defeated mice spending less time in the center of the arena when the social target was present (Bonferroni, $p<0.01$ ). While the differences in center time confirm the efficacy of the CSDS, the absence of social avoidance precludes the use of this typical endpoint to subclassify mice as stress-susceptible and stress-resilient (Krishnan et al., 2007), and suggests that the presence of the subcutaneous transmitters can affect this method of quantifying social interaction behavior. Instead, we examined the amplitude of body temperature rhythms as an alternate index of stress susceptibility (see below).

CSDS disrupted circadian rhythm of motor activity. While bouts of activity were highly entrained to light/dark cues in both groups during baseline, CSDS caused a rapid disorganization of 


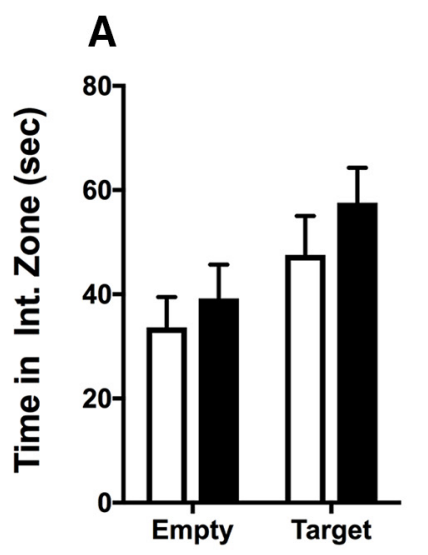

E

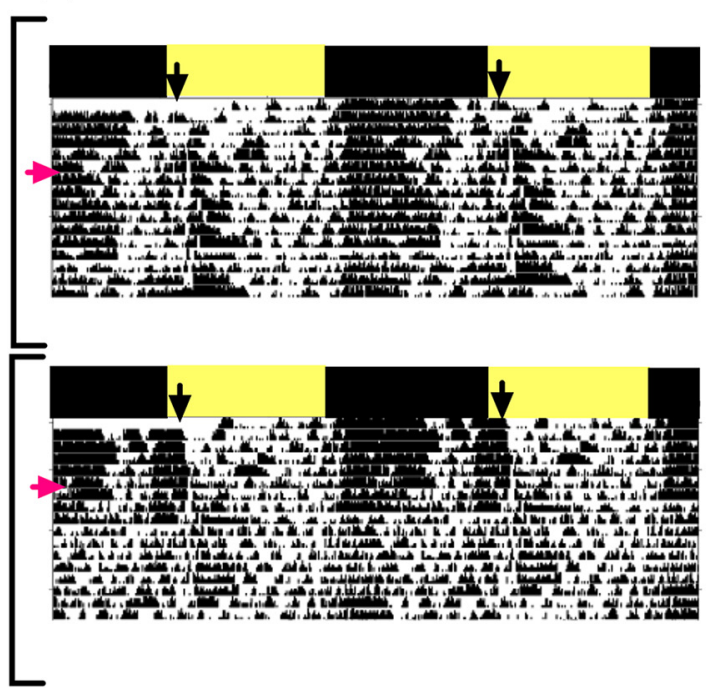

B

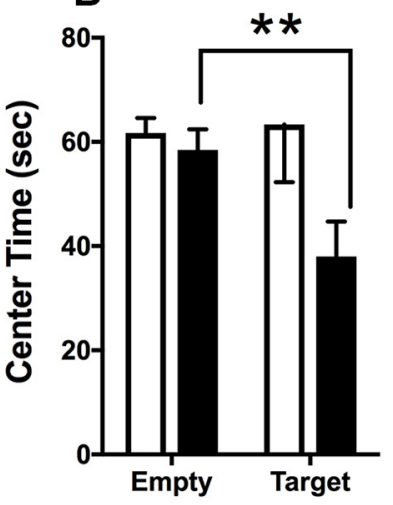

C

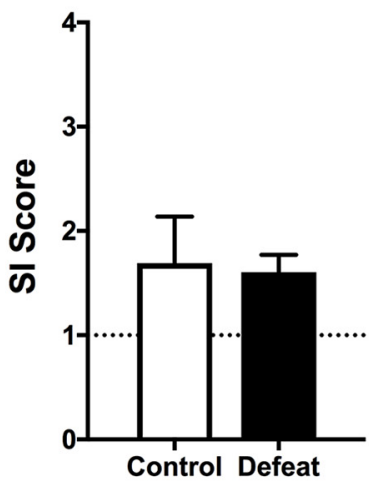

D

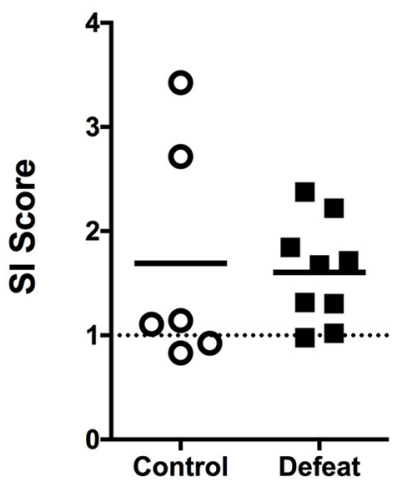

$F$

\section{Control}

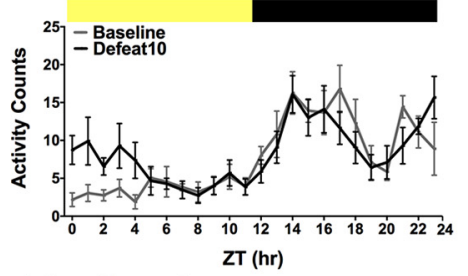

\section{Defeat}

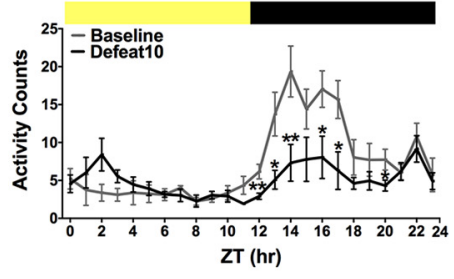

G

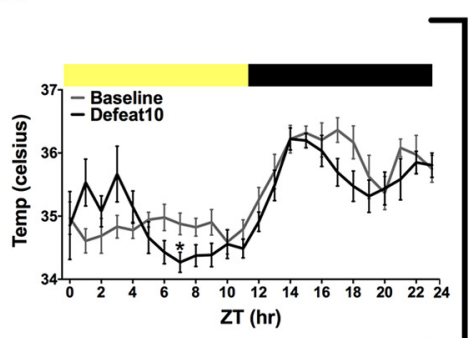

Figure 1. Effects of CSDS on SI and circadian rhythms in mice. $\boldsymbol{A}$, CSDS did not affect time (mean \pm SEM, seconds) spent in the social interaction zone in the presence or absence of a novel CD1 mouse, although $(\boldsymbol{B})$ defeated mice spent less time in the center of the arena. $\boldsymbol{C}$, CSDS did not affect mean ( \pm SEM) SI scores, and (D) the score distribution was not consistent with subgroups of susceptible and resilient mice. $\boldsymbol{E}$, Actigraphs from representative control (top) and defeated mice (bottom). Activity remained entrained to the light/dark cycle throughout the experiment (day 1 , red arrow) in control mice, whereas it became disorganized and independent of light cues in the defeated mice soon after the start of the (SDS regimen (black arrow). $F$, Mean hourly motor activity counts ( \pm SEM) and $(\boldsymbol{G})$ body temperature measured on the final day of baseline and the final CSDS day in control (top) and defeated mice (bottom). CSDS flattened circadian rhythms of activity and of body temperature, with most changes occurring in the dark (black bar) rather than the light (yellow bar) phase. $N=6-9 /$ group. ${ }^{*} p<0.05$, between-subject comparisons (Bonferroni tests). ${ }^{* *} p<0.01$, between-subject comparisons (Bonferroni tests).

these patterns in defeated mice (Fig. $1 E$ ). Disruption of activity was also seen in control mice near the end of the 10 day CSDS regimen, a time at which all mice were being habituated to the social interaction chambers. Comparison of mean hourly activity counts on baseline day 5 and defeat day 10 revealed that amplitude was impaired in defeated mice, but not in controls (Fig. $1 F$ ). In controls, activity depended on a main effect of time (hour) $\left(F_{(23,230)}=8.30, p<0.001\right)$, consistent with circadian oscillations in activity, whereas it depended on an hour $\times$ day interaction $\left(F_{(23,368)}=3.78, p<0.001\right)$ in defeated mice. On day 10 , the amplitude of motor activity rhythm was reduced in defeated mice at ZT12-ZT14, ZT16-ZT17, and ZT20 ( $p$ values $<0.05-0.01$ ), indicating a general blunting of the rhythm. Collapsed across all days of the CSDS regimen, activity amplitude tended to be lower in defeated mice $\left(t_{(13)}=1.87, p=0.08\right)$ but did not reach statistical significance (data not shown). CSDS had qualitatively similar effects on circadian rhythm of body temperature. In controls, body temperature depended on an hour $\times$ day interaction $\left(F_{(23,230)}=2.20, p=0.002\right)$ (Fig. $\left.1 G\right)$ but differed between baseline day 5 and defeat day 10 only during ZT7 $(p<0.05)$. In defeated mice, body temperature depended on an hour $\times$ day interaction $\left(F_{(23,368)}=4.20, p<0.001\right)$, with an increase at ZT2 and ZT3 and reductions at ZT7, ZT11-ZT14, ZT16-ZT17, and ZT20 on day 10 ( $p$ values $<0.05-0.01)$, indicating a general blunting of the daily rhythm. Collapsed across the CSDS regimen, temperature amplitude was significantly lower in defeated mice $\left(t_{(13)}=1.85, p=0.04\right)$ (data not shown). Given these group differences, we used temperature amplitude to classify defeated mice into susceptible and resilient groups in Experiment 2.

\section{Effects of CSDS on circadian amplitude}

In Experiment 2, we used new cohorts of mice to examine the persistence of CSDS effects during a 5 day postdefeat (recovery) period without the potentially confounding effects of the SI test. As in Experiment 1, CSDS disrupted the circadian rhythmicity of both body temperature and motor activity. Temperature amplitude depended on a phase $\times$ group interaction $\left(F_{(2,38)}=5.52\right.$, $p=0.008$ ) (Fig. 2A); amplitude was reduced relative to baseline during the CSDS regimen in both controls and defeated mice ( $p$ values $<0.01$ ), likely reflecting the change from single housing 

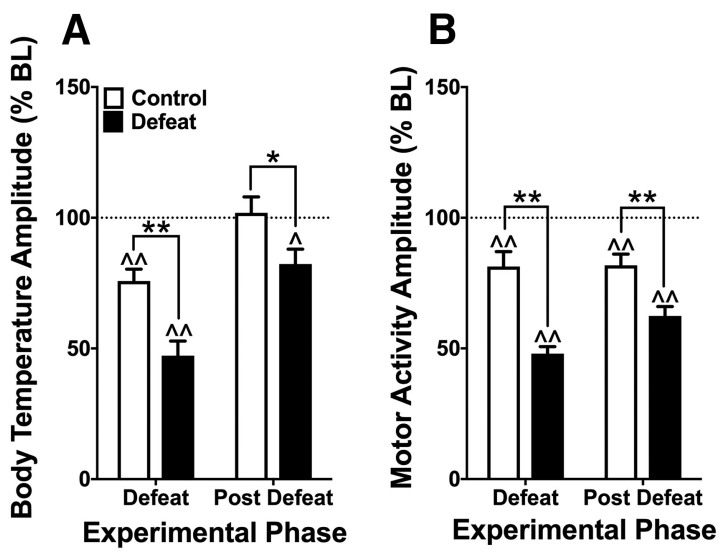

Figure 2. Persistence of CSDS effects on circadian amplitude of body temperature and motor activity during the 10 day CSDS and 5 day postdefeat (recovery) phases. $A$, Circadian amplitude of body temperature was reduced relative to baseline (BL, indicated by dotted line at $100 \%$ ) during the CDSD phase, but the effects were larger in defeated mice and persisted through the recovery phase only in defeated mice. $\boldsymbol{B}$, Circadian amplitude of motor activity was reduced relative to baseline during the CSDS and the recovery phases, but the effects were larger in defeated mice. $N=10$ or $11 /$ group. ${ }^{*} p<0.05$, between-subjects (Bonferroni tests). ${ }^{* *} p<0.01$, between-subjects (Bonferroni tests). $\wedge p<0.05$, within-subjects (Bonferroni tests). $\wedge \wedge p<0.01$, within-subjects (Bonferroni tests).

to cohousing, repeated sleep deprivation related to the testing procedures, or a combination of both. This reduction normalized in controls but persisted in defeated mice during the recovery period $(p<0.05)$ upon removal of the stressor. Temperature amplitude was lower in defeated mice than in controls during the CSDS $(p<0.01)$ and recovery $(p<0.05)$ periods. Circadian amplitude of motor activity also depended on a phase $\times$ group interaction $\left(F_{(2,38)}=12.66, p<0.001\right)$ (Fig. $\left.2 B\right)$ : amplitude was reduced relative to baseline during the CSDS regimen in both controls and defeated mice $(p$ values $<0.01)$. Unlike core body temperature amplitude, the mean reductions in motor activity amplitude persisted in both controls and defeated mice during the recovery period ( $p$ values $<0.01$ ). Importantly, however, motor activity amplitude was lower in defeated mice during the CSDS and recovery periods ( $p$ values $<0.01$ ).

\section{Effects of CSDS on sleep and wakefulness}

CSDS produced dramatic alterations in sleep architecture, some of which endured throughout the recovery period. The effects of CSDS on time spent in PS, akin to rapid eye movement (REM) sleep but lacking electrooculographic measurements, depended on a phase $\times$ group interaction $\left(F_{(2,38)}=6.67, p=0.003\right)$ (Fig. $3 A)$. The mean PS time never differed from baseline in controls, whereas it was significantly elevated in defeated mice during the CSDS regimen $(p<0.01)$, before normalizing during the recovery period. PS times were higher in defeated mice than in controls during the CSDS regimen $(p<0.01)$ but not the recovery period. The time course of mean PS times across the $20 \mathrm{~d}$ of the experiment depended on a day $\times$ group interaction $\left(F_{(19,361)}=3.48\right.$, $p<0.001$ ) (Fig. 3B). PS times were higher in defeated mice on CSDS days 4-7 and day 9, compared with controls ( $p$ values $<0.05-0.01)$. The effects of CSDS on the mean number of PS bouts also depended on a phase $\times$ group interaction $\left(F_{(2,38)}=\right.$ $7.657, p=0.002$ ) (Fig. 3C). The mean number of PS bouts never differed from baseline in controls, whereas it was higher in defeated mice during CSDS $(p<0.01)$ and remained elevated through the recovery period $(p<0.05)$. The mean number of PS bouts was higher in defeated mice than in controls during the
CSDS regimen $(p<0.01)$ but not the recovery period. The time course of the mean daily number of PS bouts depended on a day $\times$ group interaction $\left(F_{(19,361)}=4.706, p<0.001\right)($ Fig. $3 D)$. The number of bouts was higher in defeated mice on all days of the CSDS regimen and recovery days $4-5$ ( $p$ values $\leq 0.05-0.01$ ).

Similarly, the effects of CSDS on time spent in SWS, a type of non-REM sleep characterized by a predominance of lowfrequency delta waves, depended on a phase $\times$ group interaction $\left(F_{(2,38)}=5.06, p=0.011\right)$ (Fig. $\left.4 A\right)$. Mean time SWS times never differed from baseline in controls, whereas they were significantly higher in defeated mice during the CSDS regimen $(p<0.01)$ and the recovery period $(p=0.05)$. SWS times were higher in defeated mice than in controls during the CSDS regimen $(p<0.01)$ but not the recovery period. The time course of mean SWS times depended on a day $\times$ group interaction $\left(F_{(19,361)}=2.437, p=\right.$ 0.001 ) (Fig. $4 B$ ). SWS times were higher in defeated mice on CSDS days $1-4,6$, and 8 , but not during recovery, compared with controls ( $p$ values $<0.05-0.01$ ). Interestingly, CSDS failed to cause corresponding changes in the number of SWS bouts, which depended on a main effect of phase only $\left(F_{(2,38)}=35.349, p<\right.$ 0.001 ) (Fig. 4C). Both control and defeated mice showed increases in SWS bouts during the CSDS regimen $(p<0.01)$, suggestive of a general effect related to the initial transition from single to group housing and/or sleep deprivation related to the testing procedures, with no differences during recovery. The time course of mean daily number of SWS bouts depended on a main effect of day only $\left(F_{(19,361)}=14.19, p<0.001\right)$ (Fig. $\left.4 D\right)$, with no group differences at any point.

Accompanying CSDS-induced increases in sleep were corresponding decreases in wakefulness. CSDS did not affect quiet wakefulness time or bouts (data not shown), whereas effects on time spent in AW depended on a phase $\times$ group interaction $\left(F_{(2,38)}=5.80, p=0.006\right)$ (Fig. 5A). Mean AW times never changed in controls, whereas they were significantly reduced in defeated mice during CSDS $(p<0.01)$, with no deviation from baseline in either group during the recovery period. AW times were lower in defeated mice than in controls during the CSDS regimen $(p<0.01)$ but not the recovery period. The time course of mean AW times depended on a day $\times$ group interaction $\left(F_{(19,361)}=3.715, p<0.001\right)$ (Fig. 5B). AW times were lower on baseline day 3, CSDS days 1-2, 4-7, and 9, compared with controls ( $p$ values $<0.05-0.01$ ). Despite changes in AW time, CSDS did not affect the number of AW bouts (Fig. $5 C, D$ ).

To determine whether CSDS altered latencies to enter PS, SWS, or AW, we identified time to the first bout of each vigilance state on baseline day 5, CSDS days 1, 5, and 10, and postdefeat day 5 (i.e., recovery). Change from baseline latency was calculated as latency - baseline day 5 latency (seconds). Because the daily CSDS sessions occurred during the light phase, latencies were calculated for the dark phase only (Table 2). In general, latencies to PS were decreased throughout CSDS and into the recovery period in both defeated mice and controls, suggestive of a general effect related to the transition from single to group housing and/or sleep deprivation related to the testing procedures. However, latency to PS also depended on a day $\times$ group interaction $\left(F_{(3,36)}=2.990, p=0.044\right)$. Latencies to PS were significantly shorter in defeated mice than in controls on day $10(p<0.05)$ but normalized during recovery. In contrast, latencies to SWS never differed between defeated and control mice at any time point. Similar to PS, latency to AW depended on a day $X$ group interaction $\left(F_{(3,36)}=4.794, p=0.017\right)$. Latencies to the first bout of AW were higher in defeated mice than in controls on day $10(p<$ 0.05 ) but normalized during recovery. 
A

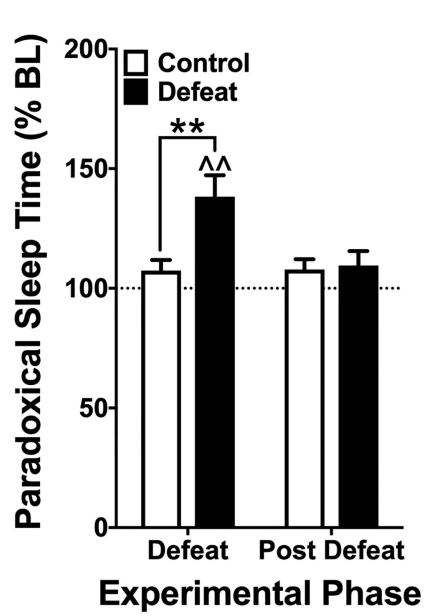

C

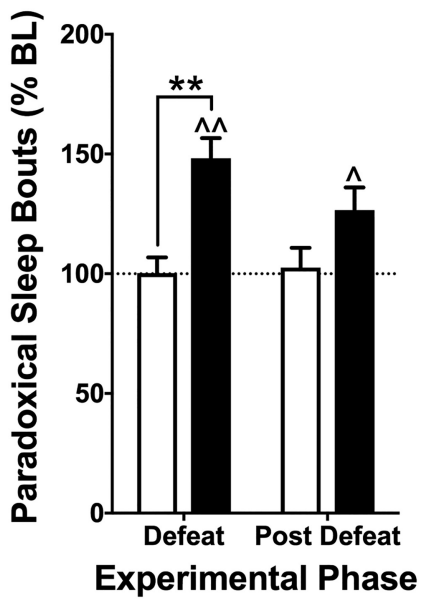

B

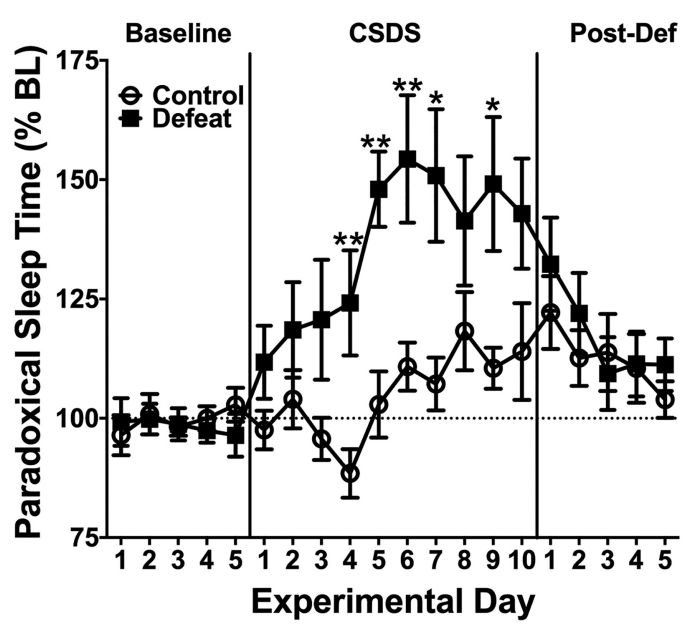

D

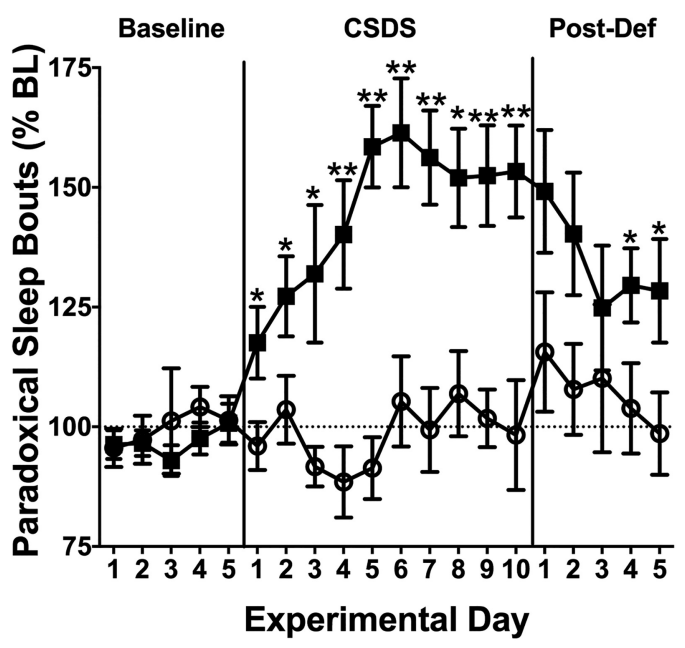

Figure 3. Effects of CSDS on PS during the 10 day CSDS and 5 day postdefeat (recovery) phases. $\boldsymbol{A}$, Mean time (expressed as percentage baseline $[B L] \pm S E M)$ spent in PS was increased in defeated mice relative to $B L$ and controls during the CDSD phase, but this effect did not persist through the recovery phase. $\boldsymbol{B}$, Detailed time course shows a progressive onset of increases in PS time in defeated mice followed by rapid normalization during recovery. $\boldsymbol{C}$, The number of PS bouts was increased in defeated mice relative to $B L$ and controls during the CDSD phase, and remained higher than BL during the recovery phase. $D$, Detailed time course shows a progressive onset of increases in defeated mice that persisted through recovery. $N=10$ or $11 /$ group. ${ }^{*} p<0.05$, betweensubjects (Bonferroni tests). ${ }^{* *} p<0.01$, between-subjects (Bonferroni tests). $\wedge p<0.05$, within-subjects (Bonferroni tests). $\wedge \wedge p<0.01$, within-subjects (Bonferroni tests).

Effects of acute and chronic SDS on qEEG power spectra Using a multitaper analysis, we derived the relative power of the following frequency bands: delta $(0.5-4 \mathrm{~Hz})$, theta $(4-12 \mathrm{~Hz})$, low gamma $(30-58 \mathrm{~Hz})$, and high gamma $(62-100 \mathrm{~Hz})$ separately for each vigilance state. These bands are reportedly dysregulated in human depression (Steiger and Kimura, 2010) and in laboratory animals exposed to stress (Nedelcovych et al., 2015). Analyses focused on baseline day 5, defeat day 1 , and defeat day 10 . CSDS effects on delta power during PS depended on a day $X$ group interaction $\left(F_{(2,34)}=3.67, p=0.036\right.$ ) (Fig. 6A). Delta power did not change from baseline in controls, whereas it was higher on day 1 of CSDS in defeated mice, compared with baseline $(p<0.01)$ and controls $(p<0.05)$. There were no differences by defeat day 10. Effects on theta power depended on a main effect of group only $\left(F_{(1,16)}=8.73, p=0.009\right)$, indicating that theta power during PS was higher in defeated mice than in controls, regardless of day $(p<0.01)$. Thus, whereas the increase in delta power was rapid but transient, the increase in theta was both rapid and stable throughout the CSDS regimen. CSDS did not affect low or high gamma power during PS. The CSDS procedure produced qualitatively different effects on qEEG power during SWS (Fig. 6B). Effects on delta power depended on a significant main effect of day only $\left(F_{(2,38)}=4.34, p=0.02\right)$, indicating that both groups exhibited increases in delta power on defeat day 1 $(p<0.01)$ but not defeat day 10 , suggestive of a general effect related to the initial transition from single to group housing or sleep deprivation related to the testing procedures. Effects on theta power depended on a day $\times$ group interaction $\left(F_{(2,38)}=4.32, p=0.02\right)$. Theta power never deviated from baseline in controls but was significantly increased in defeated mice on defeat day $1(p<0.05)$. Although neither group differed from baseline on defeat day 10, theta power was significantly lower in defeated mice than in controls $(p<0.05)$, opposite to the pattern observed during PS. CSDS did not affect low gamma, but effects on high gamma depended on a main effect of day $\left(F_{(2,38)}=\right.$ $7.82, p=0.001)$, with power increased in both groups on both day $1(p<0.05)$ and day $10(p<0.01)$, likely reflecting the transition to group housing and/or sleep deprivation related to testing. The CSDS procedure affected all power bands during AW (Fig. 6C). Effects on delta power depended on a main effect of day only $\left(F_{(2,38)}=6.54, p=0.004\right)$, with increases in both groups relative to baseline on day $1(p<0.01)$, which normalized by day 10 . Likewise, effects on theta power depended on a main effect of day only $\left(F_{(2,38)}=12.39, p<0.001\right)$, with increases in both groups relative to baseline on day $1(p<0.01)$, and subsequent normalization by day 10 . Effects on low gamma power depended on a day $\times$ group interaction $\left(F_{(2,38)}=4.76, p=0.014\right)$. Low gamma power was higher than baseline in controls on day $1(p<0.01)$ but not day 10 , whereas it was lower than baseline in defeated mice on day 10 $(p<0.05)$. Relative to controls, low gamma power was reduced in defeated mice on day $1(p<0.01)$ and day $10(p<$ $0.05)$. Effects on high gamma power depended on a day $\times$ group interaction $\left(F_{(2,38)}=5.07, p=0.011\right)$. High gamma power was higher than baseline in controls on day $1(p<$ 0.01 ), but not by day 10 and was unchanged in defeated mice. High gamma power was higher in controls than in defeated mice on day $1(p<0.01)$ but not day 10. Overall, CSDS produced visible alterations in qEEG spectrograms (Fig. 6D), which in defeated mice are indicated by a flattening of the normal circadian rhythmicity of spectral power during both sleep and wakefulness. 
Circadian and sleep effects of CSDS in susceptible and resilient mice

We used a median split of deviation of body temperature amplitude from baseline during the recovery period to divide mice from Experiment 2 susceptible and resilient subpopulations (i.e., $<$ median $=$ susceptible; $>$ median $=$ resilient $)$ (Fig. 7A) and reanalyzed sleep and circadian endpoints using these new group classifications. We report here only analyses exposing differential effects in resilient and susceptible mice. Time spent in PS depended on a phase $\times$ group interaction $\left(F_{(4,36)}=4.10, p=0.008\right)$ (Fig. $\left.7 B\right)$. Relative to baseline, PS times increased during CSDS in both resilient mice and susceptible mice $(~ p$ values $<0.01$ ), but this effect persisted through recovery only in susceptible mice $(p<0.05)$. Additionally, only susceptible mice differed from controls during CSDS ( $p$ values $<0.05$ ), with no differences during recovery. PS bouts depended a phase $\times$ group interaction $\left(F_{(4,36)}=4.19, p=0.007\right.$ ) (Fig. $7 C$ ). The number of PS bouts never differed from baseline in controls but was increased in both resilient and susceptible mice during CSDS, relative to baseline ( $p$ values $<0.01$ ) and controls ( $p$ values $<0.01$ ). PS bouts remained significantly elevated only in susceptible mice, relative to baseline $(p<0.05)$. Circadian rhythms of body temperature and motor activity were also differentially altered in susceptible and resilient mice. The effects of CSDS on temperature amplitude depended on a phase $X$ subpopulation interaction $\left(F_{(4,36)}=5.623, p=0.001\right)$ (Fig. $\left.7 D\right)$; relative to baseline, temperature amplitude was reduced during CSDS in all groups ( $p$ values $<0.01$ ), likely reflecting the transition from single to group housing sleep deprivation related to the testing procedures. This effect persisted through the recovery period only in susceptible mice $(p<0.01)$. Similarly, relative to controls, temperature amplitude was lower in both defeated subpopulations ( $p$ values $<0.05$ ) but persisted through recovery only in susceptible mice $(p<0.01)$. Circadian amplitude of motor activity also depended on a phase $X$ subpopulation interaction $\left(F_{(4,36)}=6.302, p<0.001\right)$ (Fig. $7 E$ ): relative to baseline, activity amplitude was reduced during CSDS and during recovery in all groups $(p$ values $<0.01)$ and persisted through recovery only in susceptible mice $(p<0.01)$. Similarly, relative to controls, activity amplitude was lower during CSDS in both resilient and susceptible mice ( $p$ values $<0.01$ ) but persisted through recovery only in susceptible mice $(p<0.01)$.

\section{Effects of JDTic pretreatment on the effects of CSDS}

Because pretreatment with KOR antagonists can prevent stress effects (Van't Veer and Carlezon, 2013; Carlezon and Krystal, 2016), we examined whether treatment with the long-lasting
B

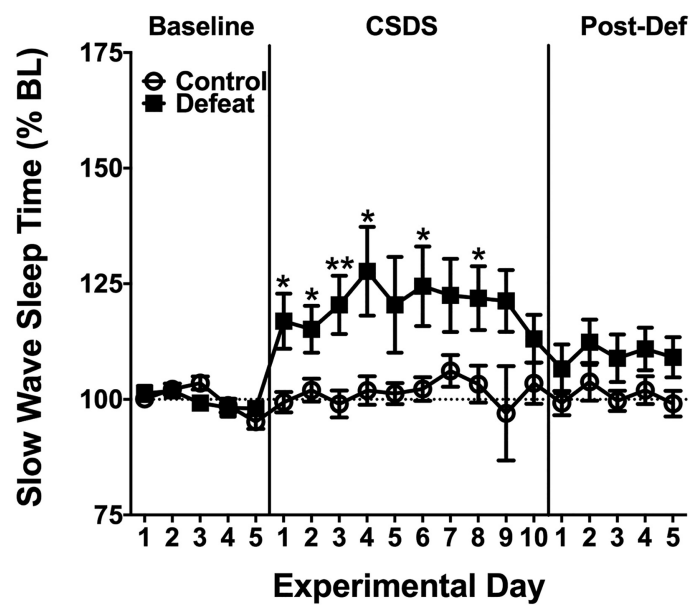

D

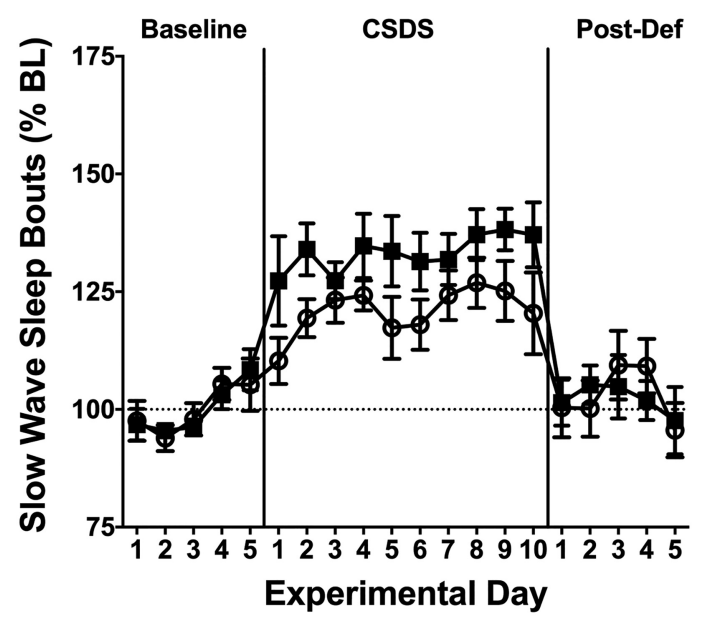

Figure 4. Effects of CSDS on SWS during the 10 day CSDS and 5 day postdefeat (recovery) phases. $A$, Mean time (expressed as percentage $B L \pm S E M)$ spent in SWS was increased in defeated mice relative to BL and controls during the CDSD phase, and within-subjects (Bonferroni tests). $\wedge \wedge p<0.01$, within-subjects (Bonferroni tests).

KOR antagonist JDTic before the onset of the CSDS paradigm would mitigate disruptions in sleep and circadian rhythm. Analyses focused on baseline day 5 , defeat day 5 , defeat day 10 , and postdefeat day 5. Of the metrics examined, two were sensitive to JDTic pretreatment: PS bouts and circadian rhythmicity of body temperature. Effects of CDSD on PS bouts depended on a day $X$ treatment interaction $\left(F_{(3,54)}=3.60, p=0.019\right)$ (Fig. $\left.8 A\right)$. Relative to baseline, the number of PS bouts were significantly elevated in vehicle-treated defeated mice on days 5 and 10 ( $p$ values $<0.01$ ), with nominal increases on postdefeat day 5 that did not reach statistical significance. In contrast, PS bouts never deviated from baseline in JDTic-treated defeated mice. Relative to vehicletreated controls, the number of PS sleep bouts was lower in JDTic-treated mice on defeat day $5(p<0.01)$ and postdefeat day $5(p<0.05)$, suggesting that JDTic pretreatment attenuated the development of changes in this metric and hastened recovery. To 
A

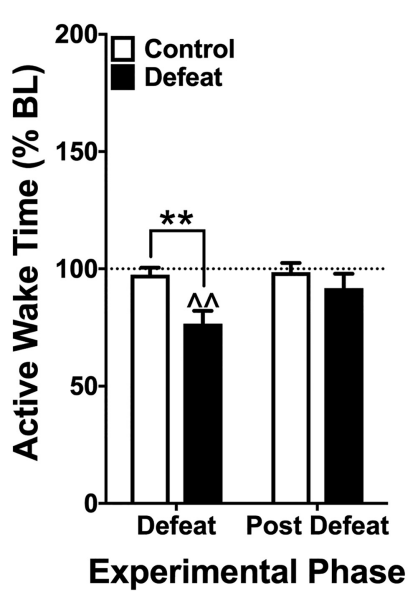

C

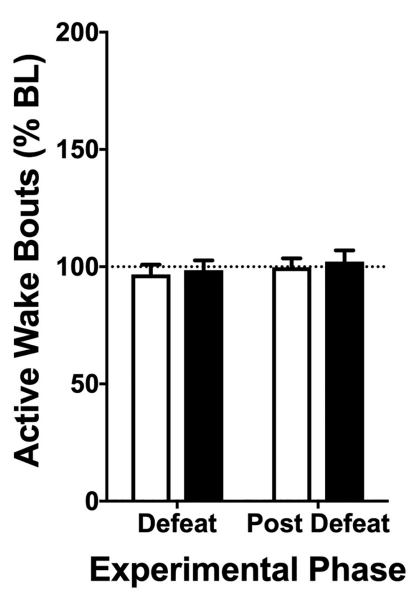

B

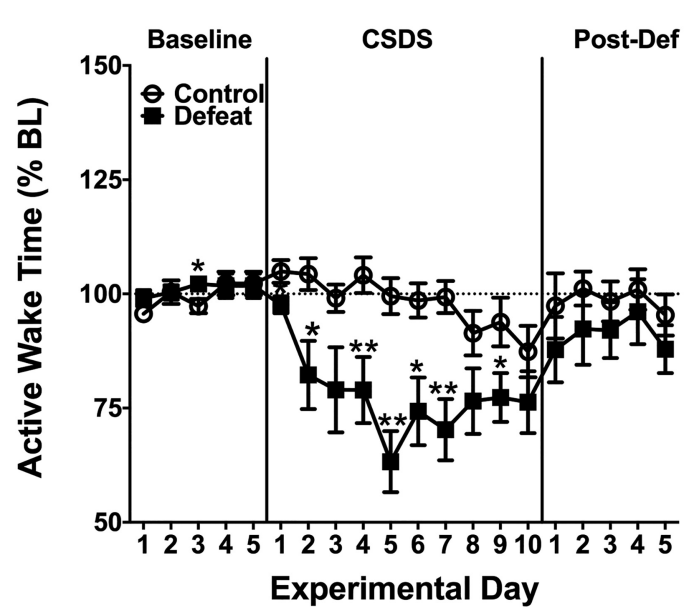

D

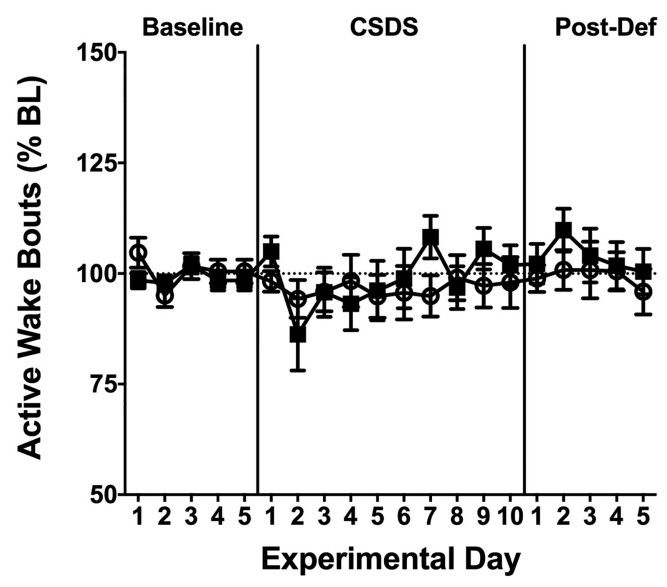

Figure 5. Effects of CSDS on AW during the 10 day CSDS and 5 day postdefeat (recovery) phases. A, Mean time (expressed as percentage $B L \pm S E M$ ) spent in SWS was decreased in defeated mice relative to $B L$ and controls during the CDSD phase, followed by rapid normalization during the recovery phase. $\boldsymbol{B}$, Detailed time course shows a progressive onset of decreases in AW time in defeated mice followed by normalization during recovery. $C$, The number of AW bouts did not change in control of defeated mice during either phase. $D$, Detailed time course confirms a lack of effect in either group. $N=10$ or $11 /$ group. ${ }^{*} p<0.05$, betweensubjects (Bonferroni tests). ${ }^{* *} p<0.01$, between-subjects (Bonferroni tests). $\wedge p<0.05$, within-subjects (Bonferroni tests). $\wedge \wedge p<0.01$, within-subjects (Bonferroni tests).

Table 2. Effects of CSDS on latency to PS, SWS, and AW during the dark phase ${ }^{a}$

\begin{tabular}{llcc}
\hline Vigilance state & Experimental day & $\begin{array}{l}\text { Control } \\
\text { (change from BL5, s) }\end{array}$ & $\begin{array}{l}\text { Defeat } \\
\text { (change from BL5, s) }\end{array}$ \\
\hline PS & CSDS day 1 & $-393.67 \pm 177.99$ & $-198.75 \pm 158.02$ \\
& CSDS day 5 & $-377.50 \pm 138.22$ & $-189.87 \pm 140.50$ \\
& CSDS day 10 & $-2.85 \pm 89.43$ & $-343.75 \pm 134.29^{*}$ \\
SWS & Postdefeat day 5 & $-118.24 \pm 167.10$ & $-60.12 \pm 183.81$ \\
& CSDS day 1 & $-169.82 \pm 91.90$ & $-45.74 \pm 57.79$ \\
AW & CSDS day 5 & $-146.25 \pm 128.42$ & $-142.38 \pm 38.01$ \\
& CSDS day 10 & $-234.81 \pm 83.63$ & $-195.14 \pm 19.58$ \\
& Postdefeat day 5 & $-168.12 \pm 89.51$ & $24.41 \pm 59.82$ \\
& CSDS day 1 & $2.97 \pm 14.01$ & $-24.00 \pm 21.59$ \\
CSDS day 5 & $72.54 \pm 92.19$ & $86.00 \pm 90.70$ \\
& CSDS day 10 & $17.13 \pm 23.73$ & $308.04 \pm 128.86^{*}$ \\
& Postdefeat day 5 & $36.25 \pm 25.11$ & $8.00 \pm 74.32$ \\
\hline
\end{tabular}

${ }^{a}$ Data are mean \pm SEM. BL, Baseline latency.

${ }^{*} p<0.05$ (between-subjects, Bonferroni tests).

examine whether JDTic affected the rate at which this change in PS bouts developed or recovered, we performed linear regression analyses on the periods of defeat days $1-5$, defeat days $6-10$, and postdefeat days $1-5$, and used the standardized $\beta$-coefficient of each regression to determine whether it was significantly different from 0 (horizontal slope). On defeat days $1-5$, the slope of the regression line in vehicle-treated defeated mice was significantly $>0(\beta=0.38, p=0.004)$, indicating a quasi-linear increase in PS bouts over time in this group, whereas the line of best fit in JDTic-treated mice did not differ from $0(\beta=0.23, p=0.12)$, suggesting a reduction in the rate at which changes in in PS bouts developed (Fig. 8B). On defeat days $6-10$, neither regression line differed from 0 , suggesting a plateau with no further changes in either group (Fig. 8C). Finally, during the postdefeat period, the slope of the regression line for vehicletreated defeated mice did not deviate from 0 , indicating absence of recovery to baseline, whereas the line of best fit for JDTictreated mice was significantly $<0(\beta=$ $-0.37, p=0.012)$, indicating an enhanced rate of recovery (Fig. $8 D$ ). There was no effect of JDTic on latencies to enter PS, SWS, or AW (data not shown). JDTic also mitigated CSDS effects on circadian rhythmicity of core body temperature, which depended on an hour $X$ day interaction in vehicle-treated mice $\left(F_{(46,690)}=\right.$ $2.03, p<0.001)$. In this group, core body temperature was lower at ZT6 and at ZT16-ZT18 on day 10 relative to baseline ( $p$ values $<0.05$ ) (Fig. 8E), indicating a flattening of the circadian rhythmicity. In JDTic-treated defeated mice, the ANOVA revealed a main effect of hour only $\left(F_{(23,552)}=16.16, p<0.001\right)($ Fig. $8 F)$, indicating no differences from baseline at any point. Interestingly, JDTic failed to affect CSDS effects on circadian rhythm of motor activity: effects depended on hour $\times$ day interactions in defeated mice treated with vehicle $\left(F_{(23,460)}=4.079, p<0.001\right)$ or JDTic $\left(F_{(23,460)}=\right.$ $3.327, p<0.001)$, with numerous differences from baseline in both vehicle- and JDTic-treated defeated mice ( $p$ values $<0.05$ 0.01 ) (Fig. $8 G, H$ ). These data indicate a flattening of circadian rhythmicity in both groups and suggest that body temperature and motor activity can vary independently. JDTic did not affect CSDS effects on SWS, AW, or qEEG (data not shown).

Effects of CSDS on mPER2 in the mesocorticolimbic pathway We used qRT-PCR was used to assess alterations in mRNA levels of the circadian rhythm gene mPer2 in mice from Experiment 2, focusing on the mesocorticolimbic system (i.e., the VTA and its major outputs: AMG, NAc, PFC), considering its role in mood and anxiety disorders (Nestler and Carlezon, 2006). Levels of mPer 2 mRNA depended on a region $\times$ pretreatment $\times$ treatment interaction $\left(F_{(3,69)}=55.97, p<0.001\right)$ (Fig. 9). CSDS increased 
A

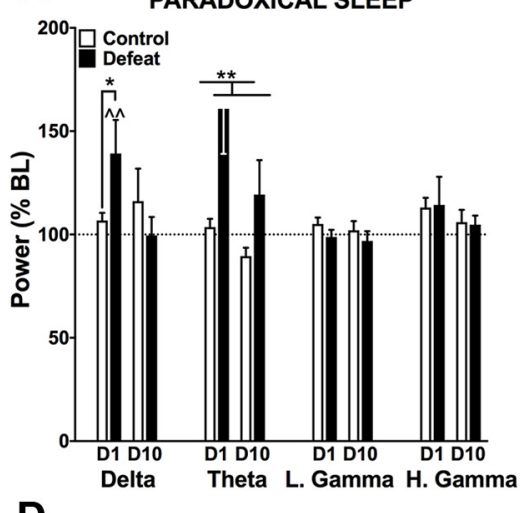

D
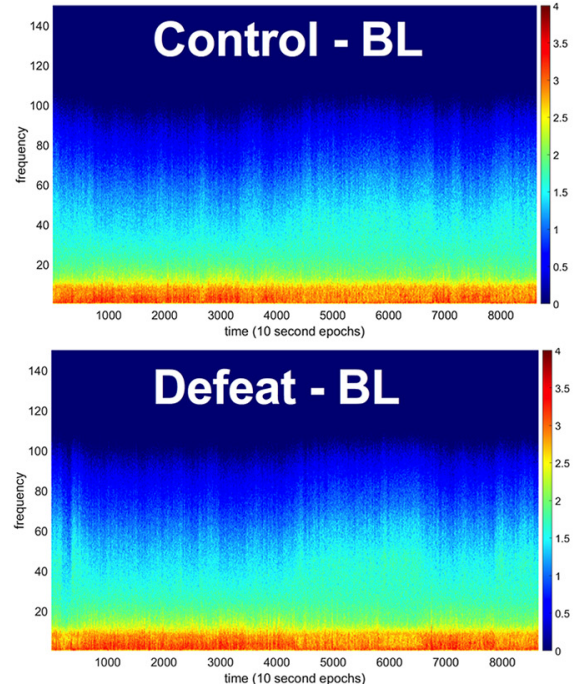

B
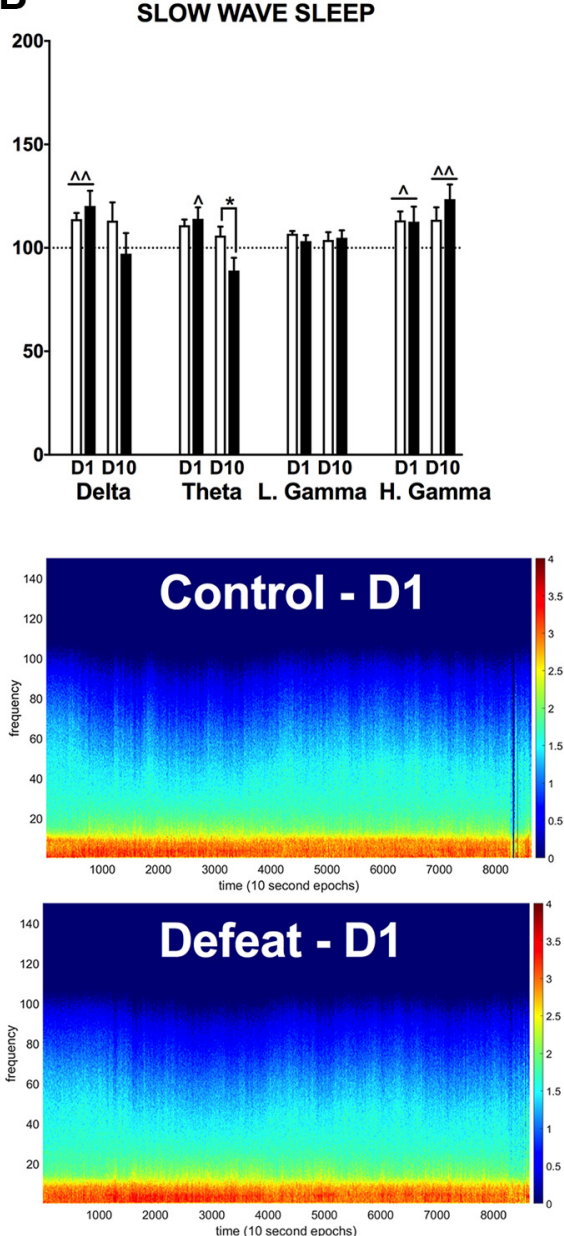

C ACtive WAKE
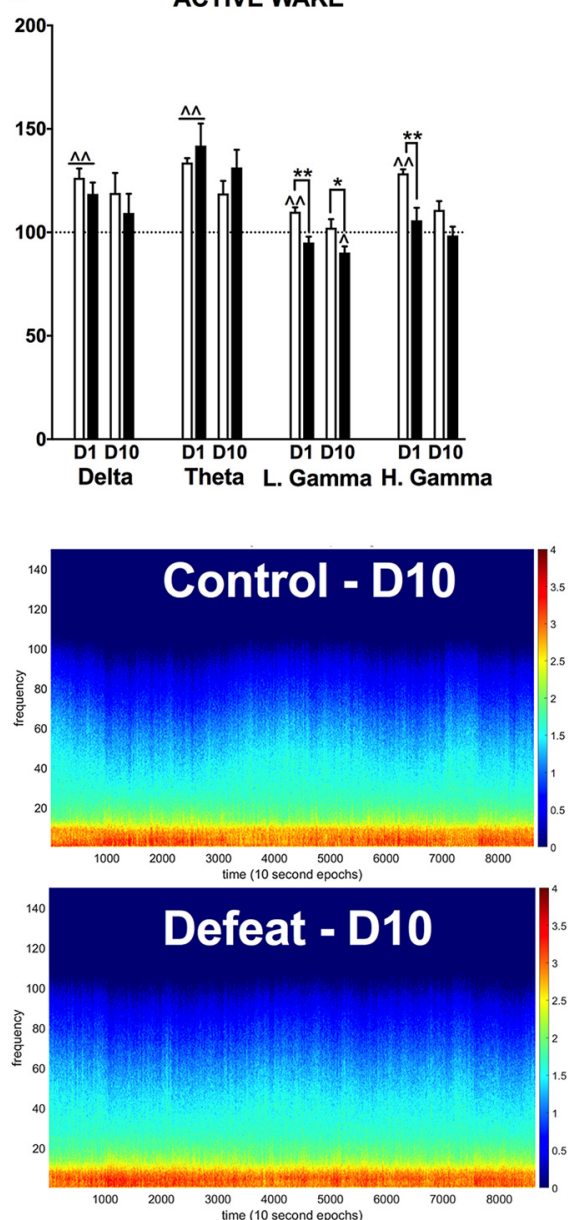

Figure 6. Effects of CSDS on spectral power for delta $(0.5-4 \mathrm{~Hz})$, theta $(4-12 \mathrm{~Hz})$, low-gamma ( $30-58 \mathrm{~Hz})$, and high-gamma (62-100 Hz) frequency bands. $A$, During PS, there were transient increases (expressed percentage BL \pm SEM) in delta power and sustained increases in theta power in defeated mice, with no differences in low-or high-gamma power. $\boldsymbol{B}$, During SWS, there were transient increases in delta power and sustained increases in high-gamma power in both control and defeated mice. In addition, there was a transient increase in theta power that evolved into a decrease in defeated mice, with no effects on low-gamma power. C, During AW, there were transient increases in delta and theta power in both control and defeated mice. In addition, there were sustained reductions in low-gamma and transient increases in high-gamma power in defeated mice. $D$, Spectrograms of group mean qEEG power on baseline day 5 , defeat day 1 , and defeat day 10 . A flattening of gamma oscillations (cyan) is particularly visible in the defeat group on day 10 of SDS. $N=10$ or $11 /$ group. ${ }^{*} p<0.05$, between-subjects (Bonferroni tests). ${ }^{* *} p<0.01$, between-subjects (Bonferroni tests). $\wedge p<0.05$, within-subjects (Bonferroni tests). $\wedge \wedge p<0.01$, within-subjects (Bonferroni tests).

$m$ Per 2 expression in the VTA and AMG and reduced it in the NAc and PFC ( $p$ values $<0.05-0.01$ ). In defeated mice treated with JDTic before CSDS, mPer2 expression did not differ from controls in the VTA or AMG, indicating blockade of CSDS effects. In the NAc, mPer2 levels were significantly higher in defeated mice that received JDTic than in controls $(p<0.01)$, suggesting that the combination of CSDS and KOR antagonism may engage cellular pathways that are different from those engaged by either alone. In the PFC, CSDS, JDTic, and the combination produced qualitatively similar reductions in mPer2 ( $p$ values $<0.01)$.

\section{Discussion}

CSDS dysregulates circadian rhythms and sleep in mice CSDS profoundly altered circadian rhythms and sleep. Effects included disruption of the circadian rhythmicity of motor activity and body temperature, such that the normal daily amplitude (rhythm strength) of these endpoints was reduced. CSDS also altered sleep, causing increases in time spent in PS and the number of PS bouts, increases in time spent in SWS, and corresponding decreases in time spent in AW. Effects were progressive, strengthening over the course of CSDS and reaching asymptotes by days $5-6$ of the 10 day regimen. Whereas some effects normalized following cessation of CSDS, others persisted through the 5 day recovery period, including reductions in circadian amplitude of body temperature and motor activity, increases in PS bouts, and time in SWS. Persistent increases in the number of PS bouts without corresponding increases in PS time indicate sleep fragmentation during this phase. The persistence of these changes is intriguing in the context of modeling stress-induced psychiatric illnesses, such as mood and anxiety disorders, which are, by definition, persistent and disruptive (American Psychiatric Association, 2013).

\section{Similarities with human psychiatric conditions}

CSDS produces behavioral signs in mice that resemble core features of MDD, including social withdrawal and anhedonia (Berton et al., 2006; Donahue et al., 2014). Interestingly, the reductions in motivation, reflected by increases in threshold levels of brain stimulation needed to sustain intracranial selfstimulation, follow approximately the same time course of alterations in sleep seen in the present studies, reaching asymp- 


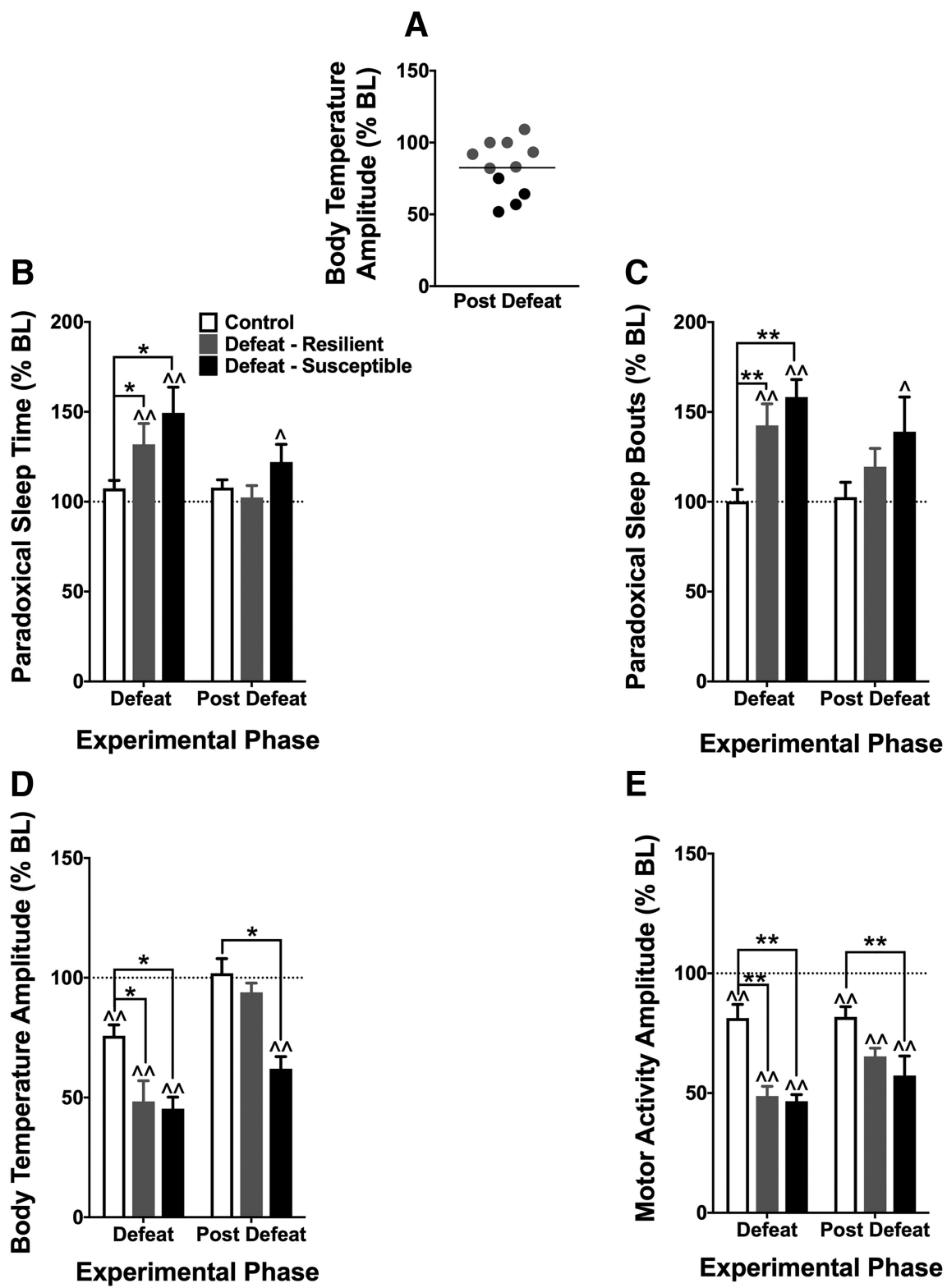

Figure 7. Effects of CSDS on sleep and circadian rhythmicity in susceptible and resilient subpopulations of defeated mice. $A$, A median split of the mean body temperature amplitude (expressed as $\% \mathrm{BL}$ ) data from the recovery period was used to classify mice into susceptible (below median; $N=4$ ) and resilient (above median, $N=7$ ) subpopulations, compared with controls $(N=$ 10). $\boldsymbol{B}$, In susceptible mice, CSDS produced larger and more sustained increases in PS time and (C) PS bouts (mean \pm SEM). $\boldsymbol{D}$, CSDS produced decreases in body temperature amplitude in both subpopulations of defeated mice during the CSDS regimen, but the effect was sustained only in susceptible mice. $E$, CSDS produced sustained decreases in motor activity amplitude in both subpopulations of defeated mice during the CSDS regimen, but the effect was larger in susceptible mice during the recovery period. ${ }^{*} p<0.05$, between-subjects (Bonferroni tests). ${ }^{* *} p<0.01$, between-subjects (Bonferroni tests). $\wedge p<0.05$, within-subjects (Bonferroni tests). $\wedge \wedge p<0.01$, within-subjects (Bonferroni tests).

tote midway through the CSDS regimen and remaining elevated during recovery (Donahue et al., 2014). The fact that antidepressants mitigate CSDS-induced behavioral alterations with time courses resembling those seen in humans (Berton et al., 2006; Zarate et al., 2006; Donahue et al., 2014) supports the validity of this procedure to study depressive disorders. Our current findings further support the notion that CSDS produces effects in mice that resemble core features of clinical depression. For example, flattening of the amplitude of circadian rhythm of body temperature, with increases during inactive phases and decreases in active phases, has been described in clinical settings (Souêtre et al., 1988; Duncan, 1996; Kronfeld-Schor and Einat,
2012). Similarly, reduced motor activity during active phases is often seen in depressive disorders (Burton et al., 2013). CSDS also produces alterations in sleep that resemble those common in MDD, including increases in PS (which shares features of REM sleep) (Armitage, 2007; Nutt et al., 2008; Steiger and Kimura 2010; Palagini et al., 2013; Medina et al., 2014). While a recent report demonstrated that defeat stress suppresses PS (Page et al., 2016), the experimental design (intermittent defeat in rats) and time course differ from those used here. Consistent with our findings, previous reports indicate that acute or short-term stress increase SWS time, and that this may represent an adaptive response (Meerlo et al., 1997; Meerlo and Turek, 2001), the absence of which contributes to depression (Medina et al., 2014). Humans with MDD also have lower latencies to the first REM bout, suggesting more rapid cycling through sleep stages (Palagini et al., 2013). Our finding that CSDS decreased latencies to PS is broadly consistent with clinical data, although the latencies quickly normalized upon cessation of the defeat regimen.

We also found that CSDS produced large effects on qEEG, including robust increases in theta and delta power during PS. Unlike delta power, however, theta power remained elevated throughout the 10 day CSDS regimen. Evidence suggests that theta oscillations during PS play a key role in the consolidation of negative/aversive memories (Hutchison and Rathore, 2015). In rats, theta is increased during PS following training in an aversive avoidance task (Fogel et al., 2009), and the degree of theta coherence between the AMG and hippocampus after fear conditioning is correlated with fear behavior (Popa et al., 2010). In humans, theta power is potentiated in the PFC during PS after exposure to emotionally negative stimuli (Nishida et al., 2009). Complementing the sleep state-dependent alterations in these specific frequency bands, comparisons of qEEG spectrograms depicting total power across the CSDS regimen revealed a visible flattening of circadian fluctuations, consistent with reductions in total EEG power and a flattening of EEG rhythmicity following maternal separation and chronic mild stress (Mrdalj et al., 2013).

\section{Stress susceptibility and resilience}

In light of previous work (Krishnan et al., 2007), we examined whether defeated mice could be segregated into susceptible and resilient subpopulations. Although this is often done via a median split of SI data, CSDS failed to produce avoidance behaviors in the present studies, and the distribution was atypically homogeneous (Krishnan et al., 2007; Donahue et al., 2014). Although 
A

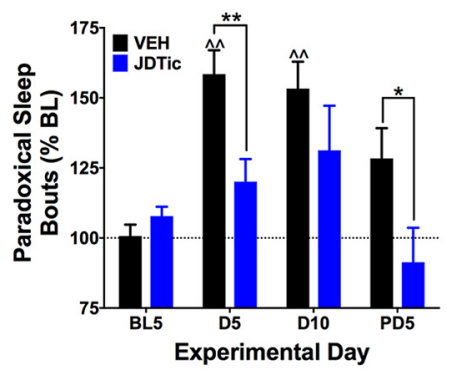

E

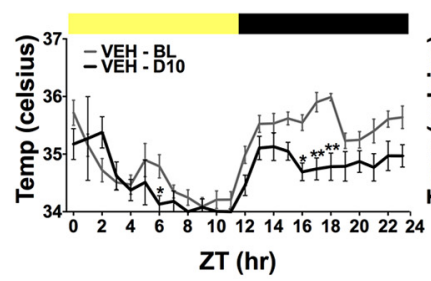

B

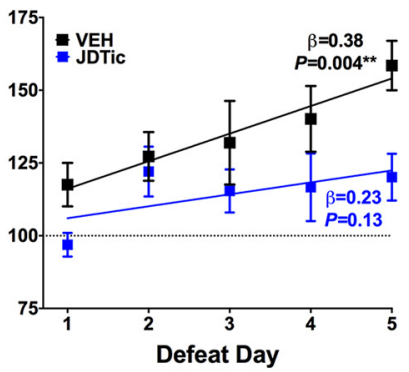

F

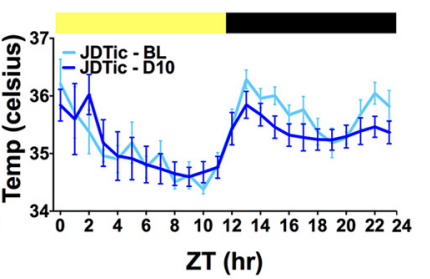

C

D
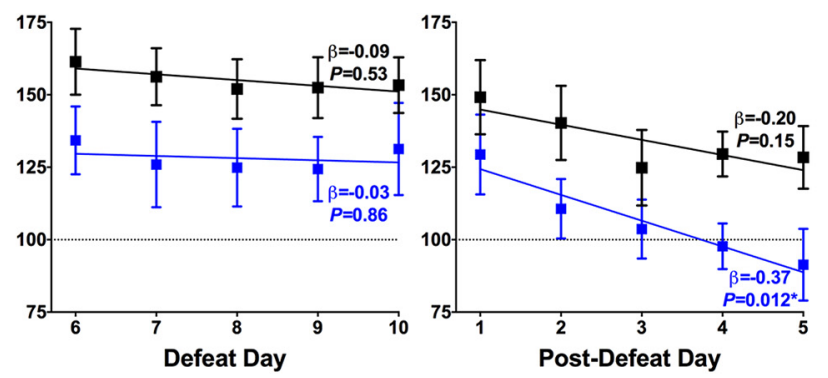

G

H

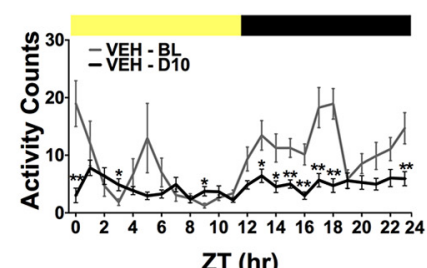

ZT (hr)

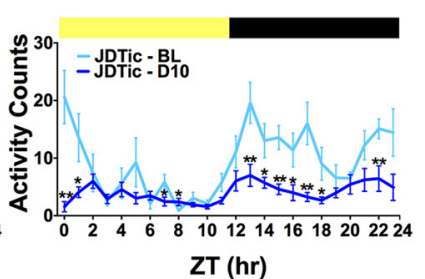

Figure 8. CSDS effects are attenuated by the KOR antagonist JDTic ( $30 \mathrm{mg} / \mathrm{kg}$, i.p.). $A$, Mean numbers of PS bouts (expressed as percentage BL \pm SEM) were lower in defeated mice during the CSDS and recovery phases ( $N=9-11$ /group). ${ }^{*} p<0.05$, between-subjects (Bonferroni tests). ${ }^{* *} p<0.01$, between-subjects (Bonferroni tests). $\wedge \wedge p<0.01$, within-subjects (Bonferroni tests). $B$, During the first $5 \mathrm{~d}$ of the CSDS regimen, there were progressive increases in PS bouts in defeated mice treated with vehicle (VEH) but not in those treated with JDTic. $C$, During the final $5 \mathrm{~d}$ of the CSDS regimen, there were no further changes in the number of PS bouts in either group. $\boldsymbol{D}$, During the 5 day recovery period, there were progressive decreases in PS bouts in defeated mice treated with JDTic but not in those treated with vehicle. ${ }^{*} p<0.05$ (standardized $\beta$-coefficient). ${ }^{* *} p<0.01$ (standardized $\beta$-coefficient). $\boldsymbol{E}$, CSDS flattened circadian rhythmicity of body temperature in defeated mice treated with vehicle (VEH), but $(\boldsymbol{F})$ this effect was blocked in JDTic-treated defeated mice. $\boldsymbol{G}$, In contrast, CSDS flattened circadian rhythmicity of motor activity in defeated mice treated with vehicle or $(\boldsymbol{H})$ JDTic. ${ }^{*} p<0.05$, between-subjects (Bonferroni tests). ${ }^{* *} p<0.01$, between-subjects (Bonferroni tests). $\wedge \wedge p<0.01$, within-subjects (Bonferroni tests).

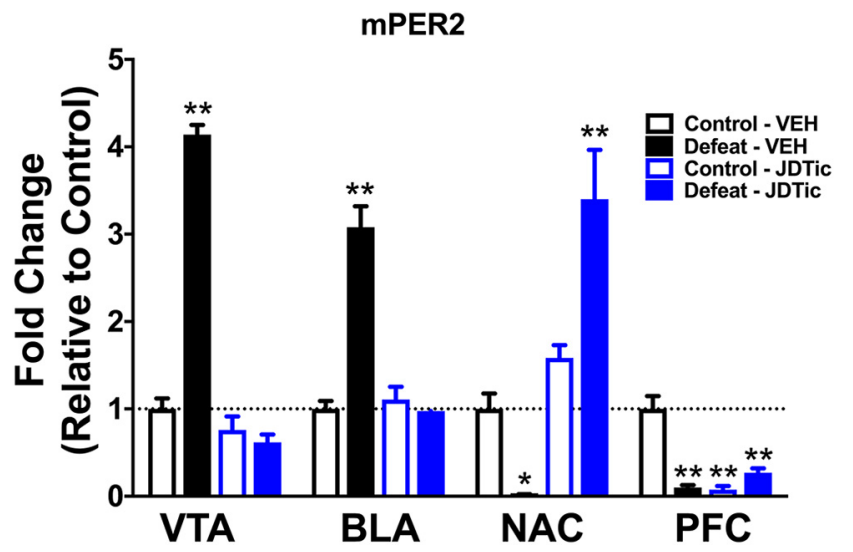

Figure 9. Effects of CSDS on mRNA levels of the Clock gene mPer2 mRNA in the mesocorticolimbic pathway. Transcript levels are expressed as "Fold Induction" (mean \pm SEM) relative to vehicle-treated controls. CSDS increased mPer2 expression in the VTA and AMG and reduced it in the NAc and PFC. JDTic blocked these effects in the VTA and the AMG and reversed them in the NAc, but had no effect in the PFC. $N=7 /$ group. ${ }^{*} p<0.05$, between-subjects (Bonferroni tests). ${ }^{* *} p<0.01$, between-subjects (Bonferroni tests).

this effect may have resolved by increasing group sizes, group sizes in our previous reports (Donahue et al., 2014, 2015) are comparable with those used here. One potential explanation for the present outcome is that the presence of the subcutaneous transmitter (the size of a small acorn situated on the back/flank) altered the microstructure of social behavior, reducing the validity of this endpoint under these conditions. We instead used circadian rhythm of body temperature amplitude, which was shown previously to serve as a secondary biomarker in mice segregated on the basis of SI (Krishnan et al., 2007). We used mean temperature amplitude data from the recovery period to segregate defeated mice into susceptible (below median) and resilient (above median) subpopulations and found that effects on PS and circadian rhythms were larger and/or more persistent in susceptible mice. These findings raise the possibility that amplitude of body temperature rhythmicity may be a viable biomarker of stress susceptibility.

\section{Role for KORs in CSDS effects}

Blockade of KORs prevented some of the physiological and molecular effects of CSDS. Accumulating evidence indicates that KORs play an important role in regulating stress responsiveness, motivation, and emotion (Bruchas et al., 2010; Knoll and Carlezon, 2010; Van't Veer and Carlezon, 2013). KOR agonists produce dysphoria in humans (Pfeiffer et al., 1986) and depressive-like effects in rodents (Carlezon et al., 2006; Bruchas et al., 2010; Muschamp et al., 2011), whereas KOR antagonists reduce stress effects (Pliakas et al., 2001; Mague et al., 2003; McLaughlin et al., 2003; Beardsley et al., 2005) and produce anxiolytic-like effects (Knoll et al., 2007). KOR antagonists tend to be more effective when given before a stressor (Van't Veer and Carlezon, 2013), as opposed to after behavioral adaptations have developed (Chartoff et al., 2012; Chartoff and Carlezon, 2014). Administration of JDTic, which produces long-lasting KOR blockade (Carroll et al., 2004; Van't Veer et al., 2012), before the start of the CSDS regimen reduced defeat-related increases in the number of PS bouts and hastened recovery. However, JDTic failed to affect CSDS effects on other sleep metrics, suggesting that stress effects on individual endpoints may depend upon distinct (but parallel) mechanisms. JDTic also mitigated CSDS effects on the circadian rhythmicity of body temperature without affecting that of motor activity, consistent with the notion that 
circuits that maintain these rhythms are at least partly nonoverlapping (Saper et al., 2005). The question of whether KOR antagonists block the effects of stress on these endpoints directly (i.e., by acutely reducing its impact) or indirectly (i.e., by producing sleep/circadian alterations that boost stress resilience) may be resolved by the development of short-acting KOR antagonists that do not require extended $(24 \mathrm{~h})$ pretreatment (Carroll and Carlezon, 2013). Finally, JDTic blocked the effects of CSDS on expression of mPer 2 in the VTA, AMG, and NAc, suggesting a critical role of KORs in transducing the molecular effects of stress in pathways that regulate motivation and emotion. Effects in the NAc suggest a paradoxical synergy between CSDS and KOR antagonism, whereas these manipulations appeared to produce the same effects in the PFC. Future studies involving highly selective molecular manipulations (Van't Veer et al., 2013a; Tejeda et al., 2017) may characterize specific contributions of KORs in each of these regions to altered sleep and circadian rhythmicity. Although the VTA and its outputs are not typically implicated in sleep or circadian rhythm, it is possible that stress effects on circadian genes in these regions (Spencer et al., 2013) may disrupt other circuits. Indeed, regulation of sleep/wakefulness involves complex and overlapping circuits with inhibitory, excitatory, and disinhibitory components, and changes in the function of one element can impact others (Saper et al., 2005). Although we generally focus on the role of the mesocorticolimbic system in mood and anxiety disorders (Nestler and Carlezon, 2006), other brain areas have been implicated in both sleep/wakefulness and KORregulated stress responses, including the dorsal raphe nucleus and locus ceruleus (Saper et al., 2005; Bruchas et al., 2011, AlHasani et al., 2013). The finding that KOR antagonism blocked some, but not all, CSDS effects is broadly consistent with previous work showing that JDTic can block corticotropin-releasing factor-induced enhancements of the acoustic startle response (Van't Veer et al., 2013b) but not CSDS-induced elevations in intracranial self-stimulation thresholds (Donahue et al., 2015), and fits with recent conceptualizations of psychiatric illnesses as conditions composed of neurobiologically distinguishable domains rather than a rigid set of symptoms with a single pathophysiology (Cuthbert and Insel, 2013).

In conclusion, use of endpoints, including sleep and circadian rhythmicity of body temperature and motor activity, has advantages for studies of stress-related disorders in laboratory animals. Foremost, these same endpoints can be studied in humans, as opposed to the endpoints from other commonly used tests (e.g., tail suspension test, elevated plus maze) that were designed as drug screening assays but have evolved into proxies for depressive- and anxiety-like effects. Considering that persistence is a defining characteristic of psychiatric illness, the CSDS effects that persist beyond the termination of the stress, circadian rhythmicity of body temperature and motor activity, PS bouts, and time spent in SWS, represent compelling starting points for more translationally oriented studies that examine the mechanisms by which stress can trigger long-lasting changes in health. Additional work is needed to determine whether these effects represent homeostatic processes that enhance recovery or feedforward processes that trigger subsequent maladaptive responses, or are more or less prevalent in stress-resilient strains (Vialou et al., 2010; Donahue et al., 2014). Refinement of endpoints that are homologous across species will facilitate the implementation of translational studies that better predict clinical outcomes in humans, enhance the success of clinical trials, and hasten the development of improved therapeutics.

\section{References}

Al-Hasani R, McCall JG, Foshage AM, Bruchas MR (2013) Locus coeruleus kappa-opioid receptors modulate reinstatement of cocaine place preference through a noradrenergic mechanism. Neuropsychopharmacology 38:2484-2497. CrossRef Medline

American Psychiatric Association (2013) Diagnostic and statistical manual of mental disorders: DSM-5. Washington, DC: American Psychiatric Association.

Armitage R (2007) Sleep and circadian rhythms in mood disorders. Acta Psychiatrica Scand Suppl 433:104-115. CrossRef Medline

Beardsley PM, Howard JL, Shelton KL, Carroll FI (2005) Differential effects of the novel kappa opioid receptor antagonist, JDTic, on reinstatement of cocaine-seeking induced by footshock stressors vs cocaine primes and its antidepressant-like effects in rats. Psychopharmacology 183:118-126. CrossRef Medline

Berton O, McClung CA, Dileone RJ, Krishnan V, Renthal W, Russo SJ, Graham D, Tsankova NM, Bolanos CA, Rios M, Monteggia LM, Self DW, Nestler EJ (2006) Essential role of BDNF in the mesolimbic dopamine pathway in social defeat stress. Science 311:864-868. CrossRef Medline

Bruchas MR, Land BB, Chavkin C (2010) The dynorphin/kappa opioid system as a modulator of stress-induced and pro-addictive behaviors. Brain Res 1314:44-55. CrossRef Medline

Bruchas MR, Schindler AG, Shankar H, Messinger DI, Miyatake M, Land BB, Lemos JC, Hagan CE, Neumaier JF, Quintana A, Palmiter RD, Chavkin C (2011) Selective $\mathrm{p} 38 \alpha$ MAPK deletion in serotonergic neurons produces stress resilience in models of depression and addiction. Neuron 71:498 511. CrossRef Medline

Burton C, McKinstry B, Szentagotai Tătar A, Serrano-Blanco A, Pagliari C, Wolters M (2013) Activity monitoring in patients with depression: a systematic review. J Affect Disord 145:21-28. CrossRef Medline

Carlezon WA Jr, Krystal AD (2016) Kappa-opioid antagonists for psychiatric disorders: from bench to clinical trials. Depression Anxiety 33:895906. CrossRef Medline

Carlezon WA Jr, Beguin C, DiNieri J, Baumann MH, Richards M, Todtenkopf MS, Rothman RB, Ma Z, Lee DY, Cohen BM (2006) Depressive-like effects of the kappa-opioid receptor agonist Salvinorin A on behavior and neurochemistry in rats. J Pharmacol Exp Ther 314:440-447. CrossRef Medline

Carroll FI, Carlezon WA Jr (2013) Development of Kappa-opioid receptor antagonists. J Med Chem 56:2178-2195. CrossRef Medline

Carroll I, Thomas JB, Dykstra LA, Granger AL, Allen RM, Howard JL, Pollard GT, Aceto MD, Harris LS (2004) Pharmacological properties of JDTic: a novel $\kappa$-opioid receptor antagonist. Eur J Pharmacol 501:111-119. CrossRef Medline

Chartoff EH, Carlezon WA Jr (2014) Drug withdrawal conceptualized as a stressor. Behav Pharmacol 25:473-492. CrossRef Medline

Chartoff E, Sawyer A, Rachlin A, Potter D, Pliakas A, Carlezon WA (2012) Blockade of kappa opioid receptors attenuates the development of depressive-like behaviors induced by cocaine withdrawal in rats. Neuropharmacology 62:167-176. CrossRef Medline

Cuthbert BN, Insel TR (2013) Toward the future of psychiatric diagnosis: the seven pillars of RDoC. BMC Med 11:126. CrossRef Medline

Donahue RJ, Muschamp JW, Russo SJ, Nestler EJ, Carlezon WA Jr (2014) Effects of striatal $\Delta$ FosB overexpression and ketamine on social defeat stress-induced anhedonia. Biol Psychiatry 76:550-558. CrossRef Medline

Donahue RJ, Landino SM, Golden SA, Carroll FI, Russo SJ, Carlezon WA Jr (2015) Effects of acute and chronic social defeat stress are differentially mediated by dynorphin/kappa-opioid receptor systems. Behav Pharmacol 26:654-663. CrossRef Medline

Duncan WC Jr (1996) Circadian rhythms and the pharmacology of affective illness. Pharmacol Ther 71:253-312. CrossRef Medline

Fogel SM, Smith CT, Beninger RJ (2009) Evidence for 2-stage models of sleep and memory: learning-dependent changes in spindles and theta in rats. Brain Res Bull 79:445-551. CrossRef Medline

Golden SA, Covington HE 3rd, Berton O, Russo SJ (2011) A standardized protocol for repeated social defeat stress in mice. Nat Protoc 6:1183-1191. CrossRef Medline

Hutchison IC, Rathore S (2015) The role of REM sleep theta activity in emotional memory. Front Psychol 6:1439. CrossRef Medline

Knoll AT, Carlezon WA Jr (2010) Dynorphin, stress and depression. Brain Res 1314:56-73. CrossRef Medline

Knoll AT, Meloni EG, Thomas JB, Carroll FI, Carlezon WA Jr (2007) 
Anxiolytic-like effects of kappa-opioid receptor antagonists in behavioral models of unlearned and learned fear in rats. J Pharmacol Exp Ther 323: 838-845. CrossRef Medline

Krishnan V, Han MH, Graham DL, Berton O, Renthal W, Russo SJ, Laplant Q, Graham A, Lutter M, Lagace DC, Ghose S, Reister R, Tannous P, Green TA, Neve RL, Chakravarty S, Kumar A, Eisch AJ, Self DW, Lee FS, et al. (2007) Molecular adaptations underlying susceptibility and resistance to social defeat in brain reward regions. Cell 131:391-404. CrossRef Medline

Kronfeld-Schor N, Einat H (2012) Circadian rhythms and depression: human psychopathology and animal models. Neuropharmacology 62:101114. CrossRef Medline

Mague SD, Pliakas AM, Todtenkopf MS, Tomasiewicz HC, Zhang Y, Stevens WC Jr, Jones RM, Portoghese PS, Carlezon WA Jr (2003) Antidepressant-like effects of kappa-opioid receptor antagonists in the forced swim test in rats. J Pharmacol Exp Ther 305:323-330. CrossRef Medline

McLaughlin JP, Marton-Popovici M, Chavkin C (2003) Kappa opioid receptor antagonism and prodynorphin gene disruption block stressinduced behavioral responses. J Neurosci 23:5674-5683. Medline

Medina AB, Lechuga DA, Escandón OS, Moctezuma JV (2014) Update of sleep alterations in depression. Sleep Sci 7:165-169. CrossRef Medline

Meerlo P, Turek FW (2001) Effects of social stimuli on sleep in mice: nonrapid-eye-movement (NREM) sleep is promoted by aggressive interaction but not by sexual interaction. Brain Res 907:84-92. CrossRef Medline

Meerlo P, Pragt BJ, Daan S (1997) Social stress induces high intensity sleep in rats. Neurosci Lett 225:41-44. CrossRef Medline

Mrdalj J, Pallesen S, Milde AM, Jellestad FK, Murison R, Ursin R, Bjorvatn B, Grønli J (2013) Early and later life stress alter brain activity and sleep in rats. PLoS One 8:e69923. CrossRef Medline

Muschamp JW, Van't Veer A, Parsegian A, Gallo MS, Chen M, Neve RL, Meloni EG, Carlezon WA Jr (2011) Activation of CREB in the nucleus accumbens shell produces anhedonia and resistance to extinction of fear in rats. J Neurosci 31:3095-3103. CrossRef Medline

Nedelcovych MT, Gould RW, Zhan X, Bubser M, Gong X, Grannan M, Thompson AT, Ivarsson M, Lindsley CW, Conn PJ, Jones CK (2015) A rodent model of traumatic stress induces lasting sleep and quantitative electroencephalographic disturbances. ACS Chem Neurosci 6:485-493. CrossRef Medline

Nestler EJ, Carlezon WA Jr (2006) The mesolimbic dopamine reward circuit in depression. Biol Psychiatry 59:1151-1159. CrossRef Medline

Nishida M, Pearsall J, Buckner RL, Walker MP (2009) REM sleep, prefrontal theta, and the consolidation of human emotional memory. Cereb Cortex 19:1158-1166. CrossRef Medline

Nutt D, Wilson S, Paterson L (2008) Sleep disorders as core symptoms of depression. Dial Clin Neurosci 10:329-336. Medline

Page GG, Opp MR, Kozachik SL (2016) Sex differences in sleep, anhedonia, and HPA axis activity in a rat model of chronic social defeat. Neurobiol Stress 3:105-113. CrossRef Medline

Palagini L, Baglioni C, Ciapparelli A, Gemignani A, Riemann D (2013) REM sleep dysregulation in depression: state of the art. Sleep Med Rev 17:377390. CrossRef Medline

Pawlyk AC, Morrison AR, Ross RJ, Brennan FX (2008) Stress-induced changes in sleep in rodents: models and mechanisms. Neurosci Biobehav Rev 32:99-117. CrossRef Medline

Pfeiffer A, Brantl V, Herz A, Emrich HM (1986) Psychotomimesis mediated by kappa opiate receptors. Science 233:774-776. CrossRef Medline

Pliakas AM, Carlson RR, Neve RL, Konradi C, Nestler EJ, Carlezon WA Jr
(2001) Altered responsiveness to cocaine and increased immobility in the forced swim test associated with elevated cAMP response element binding protein expression in nucleus accumbens. J Neurosci 21:73977403. Medline

Popa D, Duvarci S, Popescu AT, Léna C, Paré D (2010) Coherent amygdalocortical theta promotes fear memory consolidation during paradoxical sleep. Proc Natl Acad Sci U S A 107:6516-6519. CrossRef Medline

Ross RJ, Ball WA, Sullivan KA, Caroff SN (1989) Sleep disturbance as the hallmark of posttraumatic stress disorder. Am J Psychiatry 146:697-707. CrossRef Medline

Saper CB, Cano G, Scammell TE (2005) Homeostatic, circadian, and emotional regulation of sleep. J Comp Neurol 49:92-98. CrossRef Medline

Souêtre E, Salvati E, Wehr TA, Sack DA, Krebs B, Darcourt G (1988) Twenty-four-hour profiles of body temperature and plasma TSH in bipolar patients during depression and during remission and in normal control subjects. Am J Psychiatry 145:1133-1137. CrossRef Medline

Spencer S, Falcon E, Kumar J, Krishnan V, Mukherjee S, Birnbaum SG, McClung CA (2013) Circadian genes Period 1 and Period 2 in the nucleus accumbens regulate anxiety-related behavior. Eur J Neurosci 37: 242-250. CrossRef Medline

Steiger A, Kimura M (2010) Wake and sleep EEG provide biomarkers in depression. J Psychiatr Res 44:242-252. CrossRef Medline

Tang X, Sanford LD (2002) Telemetric recording of sleep and home cage activity in mice. Sleep 25:691-699. Medline

Tejeda HA, Wu J, Kornspun AR, Pignatelli M, Kashtelyan V, Krashes MJ, Lowell BB, Carlezon WA Jr, Bonci A (2017) Pathway- and cell-specific Kappa-opioid receptor modulation of excitation-inhibition balance differentially gates D1 and D2 accumbens neuron activity. Neuron 93:147163. CrossRef Medline

Van't Veer A, Carlezon WA Jr (2013) Role of kappa-opioid receptors in stress and anxiety. Psychopharmacology 229:435-452. CrossRef Medline

Van't Veer A, Yano JM, Carroll FI, Cohen BM, Carlezon WA Jr (2012) Corticotropin-releasing factor (CRF)-induced disruption of attention in rats is blocked by the $\boldsymbol{\kappa}$-opioid receptor antagonist JDTic. Neuropsychopharmacology 37:2801-2816. CrossRef Medline

Van't Veer A, Bechtholt AJ, Onvani S, Potter D, Wang Y, Liu-Chen LY, Schütz G, Chartoff EH, Rudolph U, Cohen BM, Carlezon WA Jr (2013a) Ablation of kappa-opioid receptors from brain dopamine neurons has anxiolytic-like effects and enhances cocaine-induced plasticity. Neuropsychopharmacology 38:1585-1597. CrossRef Medline

Van't Veer A, Carroll FI, Cohen BM, Carlezon WA Jr (2013b) Disruption of kappa opioid receptor function reduces stress effects on anxiety-like behavior. Soc Neurosci Abstr 39

Vialou V, Robison AJ, Laplant QC, Covington HE 3rd, Dietz DM, Ohnishi YN, Mouzon E, Rush AJ 3rd, Watts EL, Wallace DL, Iñiguez SD, Ohnishi YH, Steiner MA, Warren BL, Krishnan V, Bolaños CA, Neve RL, Ghose S, Berton O, Tamminga CA, et al. (2010) DeltaFosB in brain reward circuits mediates resilience to stress and antidepressant responses. Nat Neurosci 13:745-752. CrossRef Medline

Welsh DK, Takahashi JS, Kay SA (2010) Suprachiasmatic nucleus: cell autonomy and network properties. Annu Rev Physiol 72:551-577. CrossRef Medline

Zarate CA Jr, Singh JB, Carlson PJ, Brutsche NE, Ameli R, Luckenbaugh DA, Charney DS, Manji HK (2006) A randomized trial of an N-methyl-Daspartate antagonist in treatment-resistant major depression. Arch Gen Psychiatry 63:856-864. CrossRef Medline 